\title{
Long-Term Industry Reversals
}

\author{
Yuliang $\mathrm{Wu}^{\mathrm{a}^{*}}$ and Khelifa Mazouz \\ ${ }^{a}$ Queen's University Management School, Riddel Hall, Queen's University of Belfast, Belfast, \\ BT9 5EE, UK \\ ${ }^{b}$ Cardiff Business School, Colum Drive, University of Cardiff, Cardiff, CF10 3EU, UK
}

\begin{abstract}
This study investigates whether, how and why industry performance can drive long-term return reversals. Using data from the UK, we find a strong influence of past industry performance on stock return reversals. We also find that firms in losing industries significantly outperform those in winning industries over the subsequent five years. These industry reversals remain strong and persistent after controlling for stock and industry momentum, seasonal effects and traditional risk factors. Our results also show that industry components drive stock reversals, but industry reversals cannot be explained by past stock performance. Further analysis suggests that industry reversals are present in both good and bad states of the economy and are stronger in industries with high valuation uncertainty. This implies that industry reversals are more likely to be a result of mispricing.
\end{abstract}

* Correspondent author. Email: y.wu@qub.ac.uk Tel: 0044-2890974717: Fax: 00442890974201 


\title{
Long-Term Industry Reversals
}

\begin{abstract}
This study investigates whether, how and why industry performance can drive long-term return reversals. Using data from the UK, we find a strong influence of past industry performance on stock return reversals. We also find that firms in losing industries significantly outperform those in winning industries over the subsequent five years. These industry reversals remain strong and persistent after controlling for stock and industry momentum, seasonal effects and traditional risk factors. Our results also show that industry components drive stock reversals, but industry reversals cannot be explained by past stock performance. Further analysis suggests that industry reversals are present in both good and bad states of the economy and are stronger in industries with high valuation uncertainty. This implies that industry reversals are more likely to be a result of mispricing.
\end{abstract}

Key words: contrarian performance, industry, long term 


\section{Introduction}

DeBondt and Thaler (1985) show that loser stocks over the past three to five years outperform winners by $25 \%$ over the next three years. Many subsequent studies report evidence of long-term reversals in major international equity markets. ${ }^{1}$ However, the causes of these reversals are highly controversial in the literature. Prominent behavioural theories suggest that reversals occur due to investors' behavioural biases in forecasting firm growth (DeBondt and Thaler, 1987; Daniel et al., 1998; Barberis et al., 1998; Hong and Stein, 1999). In contrast to the behavioural interpretation, rational asset pricing models suggest that reversals are compensations that investors receive for holding risky assets (Fama and French, 1993, 1996; Zhang, 2005; Liu, 2006). Fama and French (1993, 1996) attribute reversals to distress risk. They argue that, because losers are distressed, their future returns are expected to be higher than those of winners. Consistent with rational explanations, Klein (2001) and George and Hwang (2007) also contend that reversals are caused by investors' rational reactions, possibly reflecting a delay in the payment of capital gains taxes.

This study contributes to this ongoing debate by investigating whether, how and why industry performance can drive long-term return reversals. As firms in the same industry share similar fundamentals and are affected by common shocks, arising from shifts in demand and supply for their products, industry components can cause the returns of these firms to comove (e.g. Welch, 2004; Mackay and Philips, 2005). The rational view of asset pricing suggests that this comovement represents industry-specific risk. Theoretical asset pricing models demonstrate that a firm's risk and returns can be a function of its industry characteristics (e.g. Berk et al., 1999; Calson et al., 2004, 2014; Peress, 2010; Bustamante, 2015). ${ }^{2}$ Consistent with theoretical predictions, empirical studies document that industry components can explain asset pricing regularities (e.g. Moskowitz and Grinblatt, 1999; Hou and Robinson, 2006; Hameed and Mian, 2015). Kogan (2001), Zhang (2005) and Hou et al. (2015) show that firms have greater investment adjustment costs in downturn industries. Thus, the potential risk associated with having irreversible investments in place can cause higher returns for firms operating in poorly performing industries than for those in well performing industries. The models of Fama and French (1997) and Cohen et al. (2003)

\footnotetext{
${ }^{1}$ E.g. Chou et al. (2007) in Japan, Clare and Thomas (1995) in the UK and George and Hwang (2007) in the US.

${ }^{2}$ Fama and French (1997) find that neither the Sharp-Linter-Black capital asset pricing model (CAPM) nor their three-factor model can precisely estimate industry costs of equity. Lewellen et al. (2010) show that macroeconomic (e.g. consumption, consumption-to-wealth, and investment-to-growth) based asset pricing models fail to explain cross-sectional returns for industry portfolios.
} 
indicate that poor past performance represents distress risk. Hence, firms in losing industries are expected to offer higher returns to their shareholders for bearing industry distress risk.

The behavioural models proposed by Daniel et al. (1998), Barberis et al. (1998) and Hong and Stein (1999) may also offer some insight into why industry performance may drive long-term return reversals. In Daniel et al.'s model, investors exhibit overconfidence and selfattribution biases. The degree of investors' overconfidence and self-attribution may vary over time and across industries, causing excessive mispricing and return reversals in certain industries. Similarly, Barberis et al. (1998) and Moskowitz and Grinblatt (1999) demonstrate that representativeness bias causes mispricing. If investors focus more on industry than firm specific news, the representativeness bias can lead them to extrapolate performance too far from the industry as a whole, yielding long-term reversals in industry returns. Finally, industries are viewed as the primary channel through which to disseminate information (e.g. Hong et al., 2007; Hou, 2007). In a complete and frictionless market, firms react to new information instantaneously, and industry portfolios would have no informational advantage over individual stocks in predicting returns. However, theoretical models and empirical evidence show that analyst coverage and institutional holdings are clustered at the industry level (e.g. Piotroski and Roulstone, 2004; Irvine and Pointiff, 2009; Peress, 2010). This clustering may result in a lead-lag effect within industries, as analysts and institutional investors usually pay more attention to industry leaders. The slow diffusion of information from industry leaders to followers can cause the latter to underreact to news. When traders seek to exploit sluggish price adjustments, they can create excess momentum and subsequent reversals may happen as prices revert back to their equilibrium levels (e.g. Hong and Stein, 1999).

Given the above arguments, it is surprising that little attention is given to the industry reversals and their role in explaining stock reversals. This study fills the gap. Using stocks listed on the London Stock Exchange (LSE), we find significant long-term industry reversals in the UK market. Specifically, we show that stocks in losing industries outperform those in winning industries over the subsequent five years after controlling for industry and stock momentum effects, seasonal patterns and traditional risk factors. We also show that industry reversals are stronger and more significant than stock reversals. In particular, we find that industry reversals are present in all calendar months, in neutral (neither winner nor loser) stocks and after adjusting for past stock performance. However, stock reversals exhibit strong seasonal patterns, are non-existent in neutral (neither winning nor losing) industries and disappear when we control for past industry performance. This evidence supports the 
prediction that industry components drive long-term return reversals. In the subsequent analysis, we also investigate whether the long-term industry reversals are consistent with rational explanations or are a result of mispricing. To this end, we investigate whether stock and industry reversals survive after stringent risk adjustments. We estimate risk-adjusted contrarian returns using both the Fama and French (1993) three-factor model and the Fama and French (2015) five-factor model ${ }^{3}$. We find that stock reversals completely disappear after adjusting for risk, while industry reversals remain positive and significant, albeit weak in the five-factor model. Since industry reversals are not fully explained by risk factors, it is plausible that mispricing is also at play. To shed further light on this issue, we compare the performance of the industry contrarian strategies in different states of the economy. Lakonishok et al. (1994) argue that, if loser stocks are fundamentally riskier than winner stocks, then contrarian strategies should not be profitable in bad states, in which the marginal utility of wealth is high, making loser stocks unattractive to risk-averse investors. However, if industry reversals represent a form of market inefficiency, one would expect them to be more pronounced in industries with high information uncertainty (see, e.g., Hirshleifer et al., 2013). We find that the abnormal returns of industry contrarian strategies do exist in bad states of the economy, but are higher in industries with less competition, high accruals, high idiosyncratic volatility and low analyst coverage ${ }^{4}$. These findings suggest that industry reversals are more likely to represent mispricing than driven by fundamental risk.

This study contributes to the literature in many ways. First, to the best of our knowledge, we are the first to study long-term industry reversals and their impact on the welldocumented effect of long-term stock reversals. Our study is related to the work of Moskowitz and Grinblatt (1999), who document a strong industry component in the shortterm stock momentum anomaly. However, while several studies argue that short-term momentum and long-term reversals are related (Hong and Stein, 1998; Jegadeesh and Titman, 2001), others show that they are two independent phenomena (George and Hwang, $2004)^{5}$. Thus, whether industry reversals have an impact on stock reversals remains an open empirical question. In this study, we document the presence of strong industry reversals,

\footnotetext{
${ }^{3}$ Note that it is yet to be established whether the profitability and investment factors in Fama and French (2015) reflect rational risk or mispricing. See Hou et al. (2015) for further discussions.

${ }^{4}$ Dhaliwal et al. (2011) use accruals as a proxy for information opacity, Hong et al. (2000) use firm size as a proxy for investors' attention, and Kumar (2009) uses idiosyncratic volatility as a proxy for valuation uncertainty.

${ }^{5}$ George and Hwang $(2004,2007)$ show that the momentum captured by the nearness of a stock's price to its 52 -week high does not reverse in the long term.
} 
which fully subsume the stock reversals. This finding has important implications for the asset pricing literature. Specifically, while several early studies show that contemporaneous industry returns have little impact on stock returns (e.g. Fama and French, 1997; Heston and Rouwenhorst, 1994; Griffin and Karolyi, 1998), we find that past industry performance strongly affects future stock returns. Second, we investigate whether the importance of industry returns in the conditional asset pricing is consistent with rational expectations or is better explained by behavioural biases. We find that industry reversals are more consistent with behavioural explanations and represent a challenge to the rational asset pricing models. Third, we evaluate the ability of the Fama and French (2015) five-factor model to explain anomalies outside the US. Using data from the UK, we find that the five-factor model fully explains the stock return reversals, but its ability to explain industry return reversals is relatively limited. Finally, the institutional setting of the UK market provides a unique opportunity to test the role of taxes in long-term return reversals. George and Hwang (2007) show that stock reversals in the US come exclusively in January. Since the UK tax year end is 5 April, investigating stock reversals in the month of April helps us understand whether the strong January reversals in the US are caused by tax loss selling or are merely the turn-of-theyear effect. Consistent with the tax loss selling argument, we find that stock reversals in the UK are particularly strong in April. However, the finding that industry reversals are not confined to the months of January or April is inconsistent with the tax loss selling hypothesis.

The remainder of the paper is structured as follows. Section 2 describes the data and the methodology. Section 3 provides summary statistics. Section 4 provides empirical results, and Section 5 concludes.

\section{Data, variables and methodology}

\subsection{Sample data}

Our sample consists of all stocks listed on the LSE from January 1970 to December 2011. The stock monthly and daily return series, market capitalisations, international industry classifications (ICB) and firm characteristics are extracted from Thomson Reuters DataStream. We only include common stock, filtering on the data type and company name (e.g. Griffin et al., 2010; Ince and Porter, 2006) ${ }^{6}$. The final sample includes a total of 6,216 stocks with 995,717 firm-month observations. This sample is considerably larger than those

\footnotetext{
${ }^{6}$ Details on the screening procedures are provided in Appendix A1.
} 
used in prior UK studies ${ }^{7}$. Since DataStream reports the stock return index (RI) to the nearest hundredth, stock returns computed from the RI measure may round very small returns to zero values. To avoid potential rounding errors, we set a monthly return to be missing if the RI is less than or equal to 0.10. If a stock is delisted and no delisting reason is given in DataStream, we assign the last trading month return as $-50 \%$. Shumway (1997) finds that $30 \%$ is the average return for delisted firms traded over the counter. Setting a delisting return lower than that of Shumway would cause a downward bias in the magnitude of long-term return reversals.

The industry classification is based on the 20 ICB super-sectors, which is an international standard industry classification for stocks outside the US markets ${ }^{8}$. This classification strikes a balance between having enough stocks in an industry and grouping stocks with homogeneous business environments together. The average number of stocks for each super-sector in each month is provided in Table 1. The table shows that stocks are not evenly distributed across each super-sector, ranging from 364 in industrial goods and services to 6 in the automobile and parts industry. Because the automobile and parts and telecommunications industries include fewer than 20 stocks, we use the remaining 18 industries to construct long-term winning and losing industry portfolios ${ }^{9}$.

\subsection{Variable construction}

(i) Stock's five-year past performance measure (stock_5yret): This measures a stock's return over the past 60-month period, $\frac{P_{t}-P_{t-60}}{P_{t-60}}$, plus the return from reinvesting dividends. Following DeBondt and Thaler $(1985,1987)$ and George and Hwang (2007), we set the 5-year winner (loser) dummy to unity if a stock is ranked in the top (bottom) $30 \%$ of all stocks in terms of the five-year performance measure in a given month and zero otherwise.

(ii) Long-term winning and losing industries: We construct the industries' monthly return indexes $(R I)$ based on the value-weighted monthly returns of stocks within

\footnotetext{
${ }^{7}$ While Clare and Thomas (1995) employ a random sample of 1,000 UK stocks, Wu and Li (2011) use 1,745 UK stocks that are constituents of the FTSE All Share Index.

${ }^{8}$ The ICB systems use four tiers of classifications, namely 10 industries, 20 super-sectors, 41 sectors, and 114 sub-sectors. Thomson Reuters Datastream provides only static information on ICB. It is possible that firms' industry classifications change over time. However, since the super-sectors are reasonably broad, these changes probably do not occur frequently.

${ }^{9}$ Our results are not sensitive to the inclusion or exclusion of the two industries among the benchmark industries. Further results are available upon request.
} 
the industries. Industry five-year past performance (ind_5yret) is measured as $\frac{R I_{t}-R I_{t-60}}{R I_{t-60}}$. The long-term winning (losing) industries are defined as the three industries with the highest (lowest) ind_5yret (e.g. Moskowiz and Grinblatt, 1999). We also set the 5-year winning (losing) Ind dummy to unity if a stock belongs to winning (losing) industries and zero otherwise.

(iii) Within-industry winners and losers: We create long-term within-industry winners and losers according to an individual stock's five-year return ranking within its industry. The top (bottom) $30 \%$ of stocks in a given industry are defined as within-industry winners (losers). Ind 5year winner ${ }^{\text {within }}$ (Ind 5year loser ${ }^{\text {within }}$ ) is a dummy variable with a value of one if a stock is a within-industry winner (loser) and zero otherwise. The setting of within-industry winners and losers tests whether long-term return reversals are a within-industry effect, while the construction of winning and losing industries assesses whether the reversals are an inter-industry effect.

(iv) Stock momentum: We use the price relative to the 52-week high to control for the stock momentum effect. Following George and Hwang (2004), we define $52 w k h$ Winner (52wkhLoser) as a dummy variable that equals one if $\frac{P_{i}}{h i g h_{i}}$ is ranked among the top (bottom) $30 \%$ of all sample stocks in month $t$, and zero otherwise. Here, $P_{i}$ is the price of stock $i$ at the end of month $t$ and $h i g h_{i}$ is the highest month-end price of stock $i$ during the 12-month period that ends on the last day of month $t$. George and Hwang (2004) find that the 52-week high (52wkh) measure is superior to the 12-month past performance measure (Jegdeesh and Titiman, 1993) and the industry 12-month past performance measure (Moskowitz and Grinblatt, 1999) in capturing short-term momentum.

(v) Industry momentum effect: Following Moskowitz and Grinblatt (1999), we select the three best and worst performing industries according to each industry's valueweighted past $12-$ month returns (i.e. $i n d \_12 m_{-} r e t=\frac{R I_{t}-R I_{t-12}}{R I_{t-12}}$ ). We then set the IndMomWinner (IndMomLoser) dummy to unity if a stock belongs to momentum winning (losing) industries and zero otherwise.

(vi) Neutral portfolios: We use two dummy variables to denote neutral stocks and neutral industries. Neutral ${ }^{\text {stock }}$ is equal to one if a stock belongs to neither the five- 
year winner nor loser portfolio and zero otherwise. Similarly, Neutral ${ }^{\text {industry }}$ is equal to one if a stock belongs to neither the long-term winning nor losing industries and zero otherwise. We interact Neutral ${ }^{\text {stock }}$ with 5-year winning Ind. and then with 5year losing Ind. to capture the return pattern of long-term winning and losing industries with neutral stock performance, respectively. We also interact Neutral ${ }^{\text {industry }}$ with 5-year winner and then with 5-year loser to identify the return pattern of winner and loser stocks with neutral industry performance, respectively. The four interaction terms evaluate the wideness of reversals. Specifically, we examine whether stock reversals exist in neutral industries and whether industry reversals are present among neutral stocks.

(vii) Excess industry and stock portfolios: We redefine five-year winner and loser stocks in terms of excess industry returns. An excess industry return is calculated as a stock's five-year return minus the five-year value-weighted return of the industry that the stock belongs to. All stocks are then ranked by their industry excess returns in a given month. A dummy variable 5year winner ${ }^{\text {Excess }}$ (5year loser $^{\text {Excess }}$ ) is equal to one if a stock is in the top (bottom) $30 \%$ of all stocks according to the excess industry return, and zero otherwise. This new approach to identifying winner and loser stocks takes into account past industry performance. We also redefine long-term winning and losing industries in terms of excess stock returns. All stocks are first placed into quintile portfolios according to their past five-year performance (stock_5yret). An individual stock's excess return is computed as the stock's five-year return minus the value-weighted five-year return of the quintile portfolio to which the stock belongs. The excess returns on individual stocks are then averaged within each industry. The new long-term winning and losing industries are defined as the three industry portfolios with the highest (lowest) average excess stock returns. We set the 5year winning Ind ${ }^{\text {Excess }}$ (5year losing Ind ${ }^{\text {Excess }}$ ) dummy to unity if the stock belongs to one of the new winning (losing) industries and zero otherwise. This approach takes into account past stock performance in the process of identifying the winning and losing industries. The four dummies described above can evaluate the depth of reversals between stocks and industries. If past industry performance drives long-term return reversals, industry reversals should not be wiped out after being adjusted for past stock performance. Alternatively, if past stock performance is responsible 
for the reversals, stock reversals should not disappear after being adjusted for past industry performance.

\subsection{Methodology}

Following George and Hwang (2004), Grinblatt and Moskowitz (2004) and George and Hwang (2007), we use the Fama and MacBeth (1973) style regression to measure and compare returns to different long-term investment strategies. This approach has the advantage of isolating the return to a particular investment strategy by controlling for other factors that could affect returns. It also allows us to assess the performance of the long-term investment strategies across different investment horizons.

If an investor formulates portfolios of winners and losers every month and holds these portfolios for the next $T$ months, the return earned in a given month $t$ is the equalweighted average of the returns to $T$ portfolios, each formed in one of the past $T$ months $t-j$ (for $j=1$ to $T$ ). ${ }^{10}$ Thus, the contribution of the portfolio formed in month $t$ - $j$ to the month- $t$ return can be estimated by the following cross-sectional regression:

$$
\begin{aligned}
R_{i t}= & b_{0 j t}+b_{1 j t} R_{i, t-1}+b_{2 j t} \text { size }_{i, t-1}+b_{3 j t} \text { BM }_{i, t-1}+b_{4 j t} 52 \text { wkhWinner }_{i, t-j}+b_{5 j t} \text { 52wkhLoser }_{i, t-j} \\
& +b_{6 j t} \text { IndMomWinner }_{i, t-j}+b_{7 j t} \text { IndMomLoser }_{i, t-j}+b_{8 j t} \text { 5yearWinner }_{i, t-j} \\
& +b_{9 j t} \text { 5yearLoser }_{i, t-j}+b_{10 j t} \text { 5yearwinningInd }_{i, t-j}+b_{11 j t} \text { 5yearlosingInd }_{i, t-j}+e_{i j t}
\end{aligned}
$$

where $R_{i t}$ is the return to stock $i$ in month $t$; size $_{i, t-1}$ is the log of market capitalisation; $R_{i, t-1}$ is the previous month's return; $B M_{i, t-1}$ is the past month's book-to-market ratio; and the remaining eight dummy variables are as defined earlier. The deviations from the crosssectional means of size $_{i, t-1}, R_{i, t-1}$ and $B M_{i, t-1}$ are included in the regression to control for the size effect, the bid-ask bounce and the book-to-market effect, respectively ${ }^{11}$.

\footnotetext{
${ }^{10}$ The portfolio formation and testing technique used here is in the same spirit as Jegadeesh and Titman (1993), which avoids test statistics that are based on overlapping returns. This technique makes use of the fact that ranking on the past 60 months and holding for the next 60 months produces a time series of monthly returns in which each month's return is a combination of 60 ranking strategies. For example, a January 2000 reversal strategy return is 1/60 determined by winners and losers from November 1994 to December 1999, 1/60 by rankings from October 1994 to November 1999, 1/60 by rankings from September 1994 to October 1999, and so on until the last $1 / 60$ is determined by rankings from February 1990 to January 1995. The return estimation procedure used here also takes account of other factors in predicting returns.

${ }^{11}$ For robustness purposes, we also include the Amihud (2002) illiquidity measure as an additional control in the Fama-MacBeth regression. Our results for industry-contrarian performance remain quantitatively unchanged, albeit stock-contrarian performance becomes relatively weak. These results are available upon request.
} 
The intercept $b_{0 j t}$ is the return to the risk-neutral portfolio that was formulated in month $t-j$ and has hedged out the effects of average size, bid-ask bounce, book-to-market, momentum and long-term winners and losers in predicting returns. The sum $b_{o j t}+b_{8 j t}$ is the month- $t$ return to a portfolio formed in month $t-j$ that is long in five-year winner stocks so as to hedge out all other effects. Consequently, $b_{8 j t}$ can be interpreted as the return in excess of $b_{0 j t}$, achieved by taking a long position in five-year winners $j$ months ago. The remaining coefficients have similar interpretations (see Fama, 1976).

The coefficients of $b_{10 j t}$ and $b_{11 j t}$ are the equally weighted excess returns for stocks belonging to the winning and losing industries, respectively. The coefficient difference $b_{11 j t}-b_{10 j t}$ can be interpreted as long-term industry contrarian performance resulting from a zero investment strategy that is formed by investing equally in stocks that belong to the bottom three industries and shorting equally stocks that belong to the top three industries (see, e.g. Moskowitz and Grinblatt, 1999). Similarly, the coefficient difference $b_{9 j t}-b_{8 j t}$ represents long-term stock contrarian performance resulting from a zero investment strategy of investing equally in loser stocks and shorting equally winner stocks. The comparison of the performance of these two zero investment strategies is the main interest of this study.

The total month- $t$ returns include returns to portfolios formed over the prior 60 months. For example, the total month- $t$ returns to five-year winners and five-year losers can be calculated as sums such as $S_{8 t}=\frac{1}{60} \sum_{j=1}^{60} b_{8 j t}$ and $S_{9 t}=\frac{1}{60} \sum_{j=1}^{60} b_{9 j t}$, where the individual coefficients are calculated from separate cross-sectional regressions for each $j=1, \ldots, 60$. Dividing by 60 rescales the sums to be monthly returns. We then estimate the time-series means of the month-by-month estimates of these sums (e.g. $\overline{S_{8}}, \overline{S_{9}}, \overline{S_{10}}$, and $\overline{S_{11}}$ ) and their Newey-West (1987) adjusted $t$-statistics. We also obtain risk-adjusted returns for each portfolio by employing the Fama-French (1993) three-factor and Fama-French (2015) fivefactor models. Specifically, the time series of each coefficient (e.g. $S_{8 t}, S_{9 t}, S_{10 t}$ and $S_{11 t}$ ) is regressed on the contemporaneous Fama and French factor realizations to hedge out the factor exposure. The intercept (alpha) of the time-series regression is a risk-adjusted return to 
a particular portfolio. We also regress $\left(S_{9 t}-S_{8 t}\right)$ and $\left(S_{11 t}-S_{10 t}\right)$ on the Fama-French three and five factors to obtain risk-adjusted contrarian returns.

\section{Summary statistics}

Table 1 reports basic characteristics of the 20 industry portfolios. The average percentage of total market capitalisation, the five-year raw return, and the five-year excess market return are the time-series means of the cross-sectional industry averages in each month. The fiveyear raw returns are calculated from the five-year value-weighted industry return indices, and the five-year market excess returns are calculated from the five-year industry raw returns minus the five-year FTSE All Share market index returns. In terms of the relative market capitalisations, the bank sector has the highest market share (of around 20\%). However, the automobiles and parts industry has the lowest number of firms and the lowest market share (of only $0.79 \%$ ). The average five-year raw and the market excess returns vary considerably across industries. The highest (lowest) five-year market excess return of $0.73 \%(-0.48 \%)$ is observed in the telecommunications (others) industry.

\section{Insert Table 1 and Table 2 about here}

Table 2 reports the time-series means of the cross-sectional correlations between the long-term reversal variables (see the variables in Section 2.2). The positive correlation between the five-year winner (loser) stocks and the winning (losing) industries indicates that the portfolios formed on past industry performance share some similarities with those based on past stock performance. The positive correlation between 5year winning Ind ${ }^{\text {Excess }}$ (5year losing Ind ${ }^{\text {Excess }}$ ) and 5-year winner (loser) suggests these similarities are maintained after adjusting for past stock performance. However, the negative correlation between 5-year winner $^{\text {Excess }}\left(5\right.$-year loser $\left.{ }^{\text {Excess }}\right)$ and 5-year winning (losing) Ind implies that the similarities disappear after adjusting for past industry performance. These findings highlight the importance of adjusting for stock and industry returns when defining long-term winners and losers.

\section{Results}

\subsection{Identifying long-term industry reversals}

We first estimate Eq. (1) to investigate the presence of long-term industry reversals after controlling for other variables that could affect stock returns. Table 3 reports the results for 
the entire five-year period (columns (11) and (12)) and the five individual holding periods (columns (1) to (10)). George and Hwang (2007) and Grinblatt and Moskowitz (2004) find that losers' outperformance of winners is significantly weaker outside the calendar month of January. They conclude that reversals are likely driven by tax loss selling at the tax year end. Since the UK tax year end is 5 April, we report the results separately with January and April included and with the two months excluded. This separation allows us to account for both the turn-of-the-year and the tax loss selling effects in the long-term return reversals.

\section{Insert Table 3 about here}

The key variables in Table 3 are 5year winning Ind., 5year losing Ind., 5-year winner and 5-year loser. In column (11), losing industries and loser stocks experience significant positive returns of $0.27 \%(t$-statistic $=3.86)$ and $0.11 \%(t$-statistic $=2.07)$ per month, respectively, over the five-year period. Column (12) shows that the return for losing industries is still significantly positive at $0.30 \%$ per month outside January and April. However, the return for loser stocks becomes statistically indifferent from zero outside the two calendar months. These return patterns indicate that the significantly positive returns on loser stocks come exclusively from January and April, while stocks in losing industries experience positive returns across all calendar months.

Columns (1) to (10) show the results for individual holding period. Losing industries begin to have significantly positive returns of $0.17 \%$ per month in the second year (i.e. in the window $(13,24)$ ) after portfolio formation. These returns continue to be positive and significant until the fifth year, regardless of whether January and April are included. Loser stocks also have significant positive returns of $0.11 \%$ per month in the second year, $0.12 \%$ per month in the third year and $0.16 \%$ per month in the fourth year (i.e. in the windows (13, $24),(25,36)$ and $(37,48))$. However, columns (4), (6) and (8) show that the returns on loser stocks are not statistically significant outside January and April. This finding confirms that loser stocks have a strong seasonal return pattern.

In the last three rows, we evaluate stock and industry contrarian performance. Over the five-year period, losing industries significantly outperform winning industries by $0.29 \%$ per month (column (11)). This finding is robust to the exclusion of January and April (column (12)). The industry contrarian spread is statistically significant from the second to the fifth year. Column (11) also suggests that the return on loser stocks is $0.12 \%$ per month higher than that of winner stocks. However, this outperformance disappears when January and April are excluded. The results of the individual holding periods also show that the stock 
contrarian spread is not significant outside January and April. Thus, the positive returns to loser stocks are confined to January and April, while stocks in losing industries have persistently higher returns than those in winning industries across all months. In terms of economic significance, our results suggest that the industry contrarian spread is at least two times greater than the stock contrarian spread (e.g. $0.29 \%$ against $0.12 \%$ in column (12)).

The institutional setting of the UK market provides us with a unique opportunity to test the role of taxes in long-term return reversals. Unlike that in the US, the UK tax year ends on 5 April. The calendar month of April allows us to test the hypothesis that tax loss selling $^{12}$ is fully responsible for loser stock reversals (e.g. George and Hwang, 2007; Klein, 1999). Lakonishok et al. (1991), Sias and Starks (1997) and Ng and Wang (2004) argue that, when the calendar year end is approaching, institutional investors "dress" up their portfolios by selling stocks with poor past performance ${ }^{13}$ in order to impress their clients with their stock-picking skills. The selling pressure depresses the prices of loser stocks in December. However, when the pressure eases in January, the prices revert back to equilibrium, causing losers to have higher returns. Thus, if this "window dressing" is exclusive to the calendar year end, returns in April are more likely to provide a clean test of the tax loss selling hypothesis. We run a time-series regression of the contrarian spreads on January and April dummy variables. In untabulated results, we find that the January and April dummies are both significantly positive in explaining the stock contrarian spread. However, both dummies are insignificant in the regression of the industry contrarian spread ${ }^{14}$. These findings imply that loser stock reversals can be driven by tax loss selling but it is not an exclusive driving force. In contrast, our findings imply that industry reversals are not attributable to tax loss selling or the turn-of-the-year effect.

The remaining variables in Table 3 are included as controls in Eq.(1). The significantly negative coefficient on $R_{i, t-1}$ is consistent with the month-by-month return reversals discovered by Jegadeesh (1990) and Lehmann (1990). The lagged book-to-market ratio exhibits a positive relationship with stock returns. The stock momentum effect measured

\footnotetext{
${ }^{12}$ The tax loss selling hypothesis states that investors seek to reduce their taxes by realising losses at tax year end, thereby depressing stock prices. Stock prices revert back to their equilibrium levels in the first month of the new tax year, causing higher returns.

${ }^{13}$ The window dressing effect also affects short-term momentum, as momentum profits are significantly lower in January than other calendar months (e.g. Jagadeesh and Titman, 1993; Sias and Starks, 1997).

${ }^{14}$ These results are available upon request.
} 
by the price relative to the 52-week high (George and Hwang, 2004) is much stronger than the industry momentum effect (Moskowitz and Grinblatt, 1999) ${ }^{15}$.

\subsection{Comparisons between industry and stock reversals}

In this section, we undertake pairwise nested comparisons of long-term stock reversals and long-term industry reversals. We first search for industry reversals among neutral (neither loser nor winner) stocks. The nesting procedure is then reversed by examining whether stock reversals exist in stocks with neutral industry performance. The results are reported in Table 4, without control variables for the sake of brevity.

\section{Insert Table 4 about here}

\subsubsection{Industry reversals nesting in neutral stock performance}

The two interactions Neutral ${ }^{\text {stock }} \times 5$ yearWinningInd and Neutral ${ }^{\text {stock }} \times 5$ yearLosingInd are constructed in order to identify neutral stocks within winning and losing industries. Panel A shows that losing industries with neutral stock performance have a significantly positive return of $0.30 \%$ per month (column (12)) over the five-year period. In the first year after portfolio formation, losing industries with neutral stock performance generate a significantly positive return of $0.18 \%$ per month outside January and April. This return continues to be positive and highly significant in the subsequent years, irrespective of whether January and April are included. In the fifth year, winning industries with neutral stock performance exhibit a significantly negative return of $-0.22 \%$ per month in all months (column (9)). Consistent with the results in Section 4.1, the returns on loser stocks are not significant outside January and April. The last two rows in Panel A show the presence of industry contrarian performance in stocks with neutral performance. For stocks within the middle $40 \%$ in terms of past five-year performance, stocks from losing industries still outperform those from winning industries by $0.29 \%$ per month in all months and by $0.30 \%$ per month outside January and April (columns (11) and (12)). In individual holding periods, the industry contrarian spread is significantly positive from the third to the fifth year (columns (5) to (10)). These findings suggest that industry reversals are not confined to stocks with extreme past performance.

\subsubsection{Stock reversals nesting in neutral industry performance}

\footnotetext{
${ }^{15}$ We also use past 12-month returns to identify momentum winners and losers in Eq.(1). Our main results of long-term industry reversals remain unchanged. These results are available upon request.
} 
Panel B in Table 4 provides the results on whether stock contrarian performance exists in stocks with neutral industry performance. Columns (11) and (12) show that neither winner nor loser stocks with neutral industry performance have significant returns, regardless of whether January and April are included. The returns on the winners and the losers in each individual holding period are not significant, except in the fourth year (i.e. the window (37, 48)). The last two rows show that the return to a zero-investment strategy of longing losers and shorting winners with neutral industry performance is not significant. In the first year after portfolio formation, the contrarian spread is negative and significant at the $10 \%$ level. In the subsequent years, none of the contrarian profits is significantly different from zero. In contrast to the results in Panel A, this evidence implies that extreme stock performance fails to generate significant contrarian profits for the portfolio of neutral industry performance.

\subsection{Adjusting for past performance}

This section is designed to evaluate the depth of the two types of reversals. Specifically, stock and industry reversals are adjusted by past industry and stock performance, respectively, to identify which type of reversals survives after the two adjustments. The main purpose is to control for past industry performance in stock reversals and past stock performance in industry reversals.

\subsubsection{Stock reversals in excess of past industry performance}

We first investigate whether stock reversals exist after accounting for the industry average returns. Recall that the dummy variable 5 year winner ${ }^{\text {Excess }}$ is set to unity for the top $30 \%$ of stocks with returns in excess of their industry's five-year average, while the dummy variable 5 year loser ${ }^{\text {Excess }}$ is equal to unity for the bottom $30 \%$ stocks with returns below their industry's five-year average. We refer to these dummies as excess industry portfolios. The results are shown in Panel A of Table 5.

\section{Insert Table 5 about here}

Columns (11) and (12) show that the returns to the loser excess industry portfolio over the five-year period are not significant. This portfolio's return is only significantly positive in the fourth year (column (7)), for all months, at $0.15 \%$. Recalling Table 3 , loser stocks have significant positive returns in three individual holding periods. However, here, loser stocks have positive returns only in one holding period. The last two rows in Panel A provide much stronger evidence in support of the industry effect in the stock reversals. The 
contrarian returns between the two excess industry portfolios are not significant, irrespective of whether January and April are included. The disappearance of stock reversals after controlling for industry average returns implies that long-term stock reversals are mainly driven by industry components.

\subsubsection{Industry reversals in excess of past stock performance}

Our previous results suggest that stock reversals disappear after controlling for the industry effect. Here, we investigate whether the reverse is true. If industry reversals exist and are independent of stock reversals, then industry reversals should not disappear after adjusting for past stock performance. The two dummy variables 5year winning Ind ${ }^{\text {Excess }}$ and 5year losing Ind ${ }^{\text {Excess }}$ are specifically designed to account for the impact of past stock performance on industry reversals. We refer to these two dummies as excess stock portfolios. The results are reported in Panel B.

Column (11) shows that, over the five-year period, the losing industry excess stock portfolio has a significant positive return of $0.16 \%$. The economic magnitude of this return is smaller than that in Table 4 (i.e. $0.27 \%$ ), suggesting that past stock performance only plays a partial role in the reversals for losing industries. Significant positive returns for the losing industry excess stock portfolio appear in the second, the third and the fifth year (i.e. in windows $(13,24),(25,36)$ and $(49,60))$. Furthermore, January and April have no material impact on these returns. The last two rows in Panel B show that the contrarian return between the two industry excess stock portfolios is significantly positive over the five-year period as well as in the second and fifth years. However, the significance level is slightly lower than that reported in Table 4. Overall, we conclude that past stock performance does not account for industry contrarian performance.

\subsection{Comparisons between the intra-and inter-industry reversals}

The outperformance of losing over winning industries in Section 4.1 indicates that long-term industry reversals are likely to be an inter-industry effect. However, several studies show that firm characteristics (e.g. size and value) relative to their industry average can predict stock returns (e.g. Bustamante, 2015; Cohen and Polk, 1996). This implies that under- or overperforming stocks within the same industry may also drive reversals. In other words, reversals can be an intra-industry phenomenon. To investigate this view, we include the within-industry dummies (Ind 5year winner ${ }^{\text {within }}$ and Ind 5year loser ${ }^{\text {within }}$ ) jointly with interindustry dummies (5year winning Ind and 5year losing Ind) in the Fama-MacBeth regressions. Table 6 provides the results. 


\section{Insert Table 6 about here}

The results show that neither within-industry winners nor losers have any significant returns over the five-year period. In the first year after portfolio formation, within-industry winners and losers exhibit a momentum effect, with returns of $0.10 \%$ and $-0.10 \%$ per month outside January and April (column (2)). Within-industry losers only have a positive return in the fourth year (i.e. window $(37,48))$. However, the inter-industry variable 5year losing Ind shows that losing industries have significant returns over both the five-year period (i.e. $0.27 \%$ in column (11)) and most of the individual holding periods (i.e. columns (3) to (10)). The last four rows show the intra-industry contrarian spread and the inter-industry contrarian spread. The intra-industry contrarian spread is not statistically different from zero over the five-year period and is significantly negative in the first year, outside January and April (column (2)). In contrast, the inter-industry spread is significantly positive over the five-year period as well as from the second to the fifth year. The results in this section confirm that long-term industry reversals are an inter-industry effect.

\subsection{Are long-term industry reversals driven by risk or mispricing?}

\subsubsection{Risk-adjusted returns}

This section examines whether stock and industry reversals are attributable to risk exposures. Each coefficient in the Fama-MacBeth regressions (Eq.(1)) is a time-series average of sums (e.g. $S_{7 t}$ and $S_{8 t}$ in Section 2.3) of monthly raw returns to a particular portfolio strategy. We first estimate the risk-adjusted return on a particular strategy by running a time-series regression of the strategy's sums on the Fama-French (1993) factor realizations ${ }^{16}$. We then report the intercepts (risk-adjusted returns) for the strategy in Table 7.

\section{Insert Table 7 about here}

Panel A shows that neither winner nor loser stocks have significant returns over the five-year period. The economic magnitude of the loser stocks' reversals is negligible (only 9 basis points with a $t$-statistic of 1.42) (see column (11)). The stock contrarian performance is also insignificant in the five individual holding periods. However, the returns on losing industries and industry contrarian performance remain positively significant. Thus, although the cross-sectional analysis in Table 4 shows the co-existence of stock and industry reversals

\footnotetext{
${ }^{16} \mathrm{We}$ are grateful to Gregory et al. (2013) for providing the UK Fama-French factors on their website, http://business-school.exeter.ac.uk/research/areas/centres/xfi/research/famafrench/files/
} 
in all calendar months, only industry reversals remain robust to the Fama-French three-factor adjustments. $^{17}$

Recent asset pricing studies (e.g. Novy-Marx, 2013; Fama and French, 2006, 2008; Titman et al., 2004) show that firm fundamentals, beyond those in the Fama and French (1996) model, predict stock returns. Building upon the discounted cash flow model, two additional fundamental factors, namely investment and profitability, are introduced to explain cross-sectional stock returns (Fama and French, 2015; Hou et al, 2015). To re-evaluate contrarian profits, we use the Fama and French five-factor model (Fama and French, 2015) to adjust contrarian returns. Panel B provides the results.

The results show that the returns on both loser and winner stocks over the five-year period are not significant. Loser stocks have a significantly positive return only in the fourth year (column (7)), but this return becomes insignificant when January and April are excluded. The stock contrarian returns are statistically insignificant outside January and April and in most of the individual holding periods, except in columns (7) and (9). The five-factor adjusted returns of loser and winner stocks are nearly identical to those of the three-factor model (Panel A). Stocks from losing industries still have a significantly positive return over the five-year period at $0.24 \%$, in column (11). Their returns are significantly positive from the third to the fifth year after portfolio formation. The last two rows show that the industry contrarian profits over the five-year period are positive ( $0.19 \%$ per month) and significant at the $10 \%$ level. When January and April are excluded, the profits drop slightly to $0.16 \%$ per month. The contrarian profits are also significant in three out of the five individual holding periods, albeit their magnitude is slightly smaller than those reported in the case of the threefactor model.

In untabulated results, we find that the loading on the value factor for the five-year industry contrarian spread is positive, while those on the size and market factors are negative in both the three- and five-factor models. This implies that, relative to a neutral portfolio, the industry contrarian portfolio has low market risk and tends to be heavily weighted towards big firms (which makes sense because large firms are the main contributors to industry

\footnotetext{
${ }^{17}$ Our risk adjustments are the same as the procedure of Fama and French (1996). We first estimate the portfolios' returns based on Fama-MacBeth (1973) regressions, in which we use all sample stocks (not just winners or losers) and are able to hedge out the effect of size, momentum (e.g. from both stocks and industries), and bid-ask bounce (or monthly reversals) to isolate monthly returns attributable only to whether a stock belongs to stock- or industry-past performance portfolios. This first procedure ensures that the second one, which assesses the significance of risk-adjusted returns to the portfolios of interest, produces powerful tests.
} 
performance) and value stocks (as losing industries' market value has decreased and bookto-market is large). In the five-factor model, the loadings on the investment and profitability factors are positive and negative, respectively. This suggests that industry contrarian profits come mainly from firms with low profitability (poor earnings may lead to poor performance) and those with fewer investment opportunities (firms in losing industries may find it difficult to expand their business). These findings suggest that industry contrarian returns are related to firms' fundamentals ${ }^{18}$.

However, does the above evidence mean that industry reversals are a risk premium? We argue that this may not necessarily be the case. First, even though one third of industrycontrarian performance disappears (27 vs. 19 basis points) after controlling for the Fama and French five factors, the returns on losing industries remain significantly positive over the five-year period and the contrarian performance continues to be significant in some of the individual holding periods. This means that the mispricing explanation cannot be ruled out. Second, Fama and French (2015) note that, as investment and profitability are two elements in the discounted cash flow model, the return prediction is the same whether the price is rational or irrational. Therefore, the loadings on the investment and profitability factors cannot be interpreted directly as risk exposures. Hou et al. (2015, p. 34) made a similar argument in stating that “... we wish to emphasize that the $q$-factor model is silent about the debate between rational asset pricing and mispricing. This interpretation is somewhat weaker than the risk factors interpretation per Fama and French $(1993,1996) . "$

\subsubsection{Sharpe ratio analysis}

The reduction of industry reversals in the five-factor model would be consistent with the riskbased explanation, if the five-factor model were a rational asset pricing model. However, the debate on whether the five-factor model captures risk or mispricing is still ongoing. Balakrishna et al. (2010) report that the level of profits after controlling for the unexpected change in earnings, predicts stock returns. Hirshleifer et al. (2011) provide a theoretical model in which profitability predicts returns because of investors' imperfect rationality. In the mean-variance framework, MacKinlay (1995) argues that risk-based explanations of asset pricing anomalies are bounded by the plausibility of the (squared) Sharpe ratio of the

\footnotetext{
${ }^{18}$ We also undertake an event study approach to investigate whether time-varying betas and factor loadings can explain positive returns to industry losers (e.g. Ball and Kothari, 1989). Generally, we find that the loadings on the value and investment factors have significantly increased in the post-event period. However, even after controlling for the changes in the loadings, the industry losers still have significantly positive abnormal returns. These results are available upon request.
} 
tangency portfolio that they imply. As such, the mean-variance efficient combination of the factors should have a Sharpe ratio greater than or equal to the maximum Sharpe ratio from anomalies. Table 8 reports Sharpe ratios for the three-factor model, the five-factor model, and the long-short contrarian portfolios. The monthly Sharpe ratio for each individual factor is calculated as the mean factor return divided by its standard deviation. Following MacKinlay (1995), we also estimate the maximum Sharpe ratio achievable from a given factor model as $\sqrt{\mu_{f}^{\prime} V_{f}^{-1} \mu_{f}}$, where $\mu_{f}$ is the vector of mean factor returns and $V_{f}$ is the variance-covariance matrix of the factor returns.

\section{Insert Table 8 about here}

Panel A shows that the value and investment factors in the five-factor model have the highest Sharpe ratios, of 0.10 and 0.25 . The Sharpe ratio for five-year industry contrarian performance is 0.13 , which is greater than that of the MKT, SMB and HML in the threefactor model. However, the Sharpe ratio of the five-year stock contrarian performance is nearly the same as the HML factor (0.10). Panel B shows that the three-factor model produces a maximum Sharpe ratio (0.15) that is lower than that of the industry contrarian performance $(0.25)$, but greater than that of the stock contrarian performance $(0.13)$. The tangency portfolio implied by the three-factor model encompasses the maximum risk-reward trade-off generated by stock contrarian performance, which is consistent with the risk-based explanation. In contrast, industry contrarian performance is likely to be as result of the mispricing effect in the three-factor-based risk-return world. The Sharpe ratios of the stockand industry-contrarian performance and the three-factor model are all significant at the 5\% level or lower ${ }^{19}$. For the five-factor model, the maximum achievable Sharpe ratio is 0.29 , which is greater than the Sharpe ratio associated with the industry contrarian performance and the three-factor model. Consistent with the previous results, the five-factor model is possibly more effective in explaining industry contrarian performance than its three-factor counterpart. However, the profitability and investment factors in the five-factor model do not necessarily represent risk (Fama and French, 2015; Hou et al., 2015). This is because comovement of stocks with similar profitability or investment opportunities does not contradict the mispricing effect. For instance, if investors have similar bias in processing

\footnotetext{
${ }^{19}$ Under the null hypothesis that the factor risk premiums are jointly equal to zero, [(T-N)/N]SSR is distributed as a central $\mathrm{F}(\mathrm{N}, \mathrm{T}-\mathrm{N})$, where $\mathrm{N}$ is the number of portfolios, $\mathrm{T}$ is the number of time-series observations and SSR is the squared Sharpe ratio (for details, see MacKinlay (1995) and Brennan et al. (1998)).
} 
earnings information, as modelled by Hirshleifer et al. (2011), returns on stocks with similar profitability will also comove. Hence, both investors' imperfect rationality and firm fundamentals can jointly generate the predictive power of profitability for returns. Furthermore, MacKinlay (1995) argues that the maximum Sharpe ratio for the Fama-French three-factor model is too high to be consistent with rational asset pricing. We show that the maximum Sharpe ratio of the five-factor model (0.2981) is even higher. This implies that the five-factor model may capture some elements of mispricing in stock returns ${ }^{20}$ and therefore we cannot fully rule out the mispricing effect in the industry contrarian performance.

\subsubsection{State of the economy}

Our previous results show that, although fundamental-related risks have explained some portion of industry contrarian performance, a considerable proportion of the positive returns on losing industries are left unexplained. This evidence suggests that there is still a possibility that a mispricing effect contributes towards industry reversals. To investigate this issue, we undertake a nonparametric approach similar to that of Lakonishok et al. (1994). The riskbased argument says that, if losing industries are riskier than winning industries, the former should outperform the latter particularly in good states of the economy. However, there should be no contrarian performance in bad states of the economy, in which the marginal utility of wealth is high, making the risky losing industries unattractive to risk-averse investors. To test this prediction, we examine the consistency of the performance of the industry contrarian strategies across different states of the economy. The profits of these strategies are estimated from Eq.(1).

\section{Insert Table 9 about here}

The first approach examines industry contrarian performance during extremely bad times. Our sample period includes three waves of UK economic recessions, which are defined as negative GDP growth in two consecutive quarters as reported by the Office of National Statistics (ONS). We define the rest of the sample period as "other times". Panel A of Table 9 reports the results. In the first two waves of recessions (1980: Q1 to 1981: Q2 and

\footnotetext{
${ }^{20}$ The maximum Sharpe ratios for the three- and four-factor models are 0.21 and 0.41 in US markets, as reported by Hou et al. (2015). The four-factor model is based on the $q$-theory without the value factor. Hou et al. (2015) argue that the value effect is captured by the profitability and investment factors. We find that the value factor plays an important role in explaining industry-contrarian performance. Without the value factor in the fivefactor model, industry-contrarian profits are significantly positive at the 5\% level. Hou et al. (2015) argue that the maximum Sharpe ratio for their four-factor model is not too high $(0.41)$ compared with the maximum Sharpe ratio of 1.6 , which is estimated by factors containing 28 anomalies.
} 
1991: Q1 to 1991: Q4), losing and winning industries have very similar performance. The difference between the two portfolios' returns is insignificant. However, in the most recent recession (2008: Q2 to 2009: Q3), losing industries have significantly higher returns than winning industries. This result indicates that the industry contrarian strategy is still profitable in recession times, inconsistent with the risk-based explanation. Following Lakonishok et al. (1994), we also evaluate the industry contrarian performance across four states of the economy, according to the overall market performance, using the equally weighted market return $^{21}$. The four states are the 25 worst stock return months, the remaining 149 negative return months, the 184 positive months other than the 25 best, and the best 25 months in the sample. Panel B provides the results. The first two columns show that industry contrarian strategies are profitable when the overall market experiences the worst and best performance. The evidence that industry contrarian performance also happens in bad states of the economy contradicts the risk-based explanation, suggesting that losing industries are not riskier than winning industries.

\subsubsection{Valuation uncertainty}

Previous studies show that stocks with a great amount of valuation uncertainty, which makes arbitrage risky, costly and limited, are likely to be mispriced (e.g. Merton, 1987; Shleifer and Vishny, 1997; Lam and Wei, 2011). The uncertainty can rise from a poor information environment, which can be a barrier to fair valuation of the firm by investors. Thus, if longterm industry reversals are due to mispricing, the reversals should be more pronounced for stocks within industries with high informational opacity. We use four proxies for valuation uncertainty, namely accruals, idiosyncratic volatility (IVOL), competitiveness and analyst coverage.

\section{Insert Table 10 about here}

Accruals form important accounting information which should be used by investors to adjust operating cash flows and earnings. Hirshleifer et al. (2012) and Sloan (1996) find that investors have limited resources to incorporate accruals into the share valuation process. Hirshleifer et al. (2009) show that industry-based accruals can also predict future returns for industry portfolios, implying that accruals can be a barrier to the proper valuation of industries. We define accruals in the same way as Sloan (1996). Each of the accrual elements

\footnotetext{
${ }^{21}$ Note that using real GDP growth, instead of the overall market performance, to define the states of the economy does not affect our conclusions. Further details of these results are available upon request.
} 
is aggregated at the industry level and then we calculate the industry accrual ratio ${ }^{22}$. Industries are ranked by their accrual ratios in June of each year. The median accrual ratio is used to define high and low accrual industries from July of this year to June of next year. Then, we repeat the Fama-MacBeth regressions (Eq.(1)) for stocks in high and low accrual industries. If industry contrarian performance is due to a mispricing effect, we expect industry reversals to be more pronounced in industries with high accruals. Panel A of Table 10 reports the average monthly returns across the entire five-year period (i.e. $(1,60)$ ). It shows that the industry contrarian strategy is profitable only in high accrual industries, consistent with the mispricing explanation for the industry reversals.

IVOL is also widely used as a proxy for informational opacity. Krishnaswami and Subramaniam (1999) use IVOL as a measure of information asymmetry between firm insiders and outsiders. West (1988) and Kelly (2014) document a negative association between price informativeness and IVOL. In the context of industries, industry IVOL would indicate how well industry portfolios absorbed industry and market relevant information. Boutchkova et al. (2012) show that the sensitivity of an industry's returns to political events can be a function of its IVOL. More recent studies show that IVOL is also a salient characteristic for short-sell constraints and risky arbitrage (Stambaugh et al., 2015; Mashruwala et al., 2006; Lam and Wei, 2011). We argue that, if industry contrarian performance is driven by the mispricing effect, this effect should be stronger in industries with high IVOL. To estimate industry level IVOL, we construct daily value weighted returns for the 20 industries. Industry IVOL is the standard deviation of the residuals obtained by regressing daily industry portfolio returns on the daily FTSE All Share Index return from July of the previous year to June of the current year. The 20 industries are then ranked by their IVOL, and the top (bottom) 10 industries are defined as high (low) IVOL industries from July of this year to June of the next. The sample stocks are separated into those in high and low IVOL industries for the running of the Fama-MacBeth regressions (Eq.(1)). Panel B shows that the industry contrarian strategy is profitable only in high IVOL industries, consistent with the mispricing effect.

\footnotetext{
${ }^{22}$ The accruals are defined as $A C C_{\text {industry }}=(\triangle C A-\triangle C L-\triangle C a s h+\triangle S T D E B T-D E P)$ (Sloan, 1996), where $\triangle C A=$ change in current assets during period $t ; \Delta C L=$ change in current liabilities during period $\mathrm{t} ; \Delta$ Cash $=$ the change in cash and cash equivalents during period t; $\triangle S T D E B T=$ the change in the current maturities of longterm debt and other short-term debt included in current liabilities during period $\mathrm{t}$; and $D E P=$ depreciation and amortization expenses during period t. $A C C_{\text {industry }}$ is divided by an industry's lagged total assets to obtain the accrual ratio. The aggregated elements at the industry level reflect the value-weighted accruals. We also use the equally weighted approach to calculate industry-based accruals and our results remain quantitatively the same.
} 
Competition across industries provides another important informational channel for investors to value stocks. Because firms in more concentrated industries can exercise significant pricing power on their products, they tend to disclose less information to the public, obscuring the fair value of stocks (e.g. Gal-Or, 1985; Botosan and Stanford, 2005; Ali et al., 2014). On the other hand, firms in more competitive industries can attract a great amount of attention from investors, who will demand more information from analysts (e.g. Kross et al., 1990; Lys and Soo, 1995; Das et al., 1998; Barth et al., 2001). As such, firms have more incentives to supply information to analysts in more competitive industries. Thus, the mispricing effect would predict a higher industry contrarian spread in more concentrated industries. We measure industry concentration using the Herfindahl index ${ }^{23}$. Specifically, we calculate the Herfindahl index according to the last year's financial reports for the 20 industries. The top (bottom) 10 industries are defined as highly (less) concentrated industries from July of this year to June of the next. Then, we run the Fama-MacBeth regressions for the highly and less concentrated industries separately. The results in Panel C suggest that, in highly concentrated industries, losing industry not only earn a positive return of $0.32 \%$ per month, but also significantly outperform winning industries by $0.30 \%$ per month. However, the industry contrarian spread disappears in less concentrated industries. This evidence is consistent with the notion that industry competition improves stock price adjustments to information.

Our final proxy for informational opacity is the number of analysts following. The role of financial analysts in disseminating information in financial markets has been widely documented (e.g. Grossman and Stiglitz, 1980; Admati, 1985; Bhushan, 1989). Piotroski and Roulstone (2004) and Chan and Hameed (2006) report that analyst activities help impound both industry and market relevant information into stock prices. This implies that industry contrarian performance should be weaker in industries followed by more analysts. We collect the number of analysts following each firm in June of each year. According to each stock's industry membership, the number of analysts is aggregated in a given industry and then divided by the total number of firms in the industry ${ }^{24}$. We define the top (bottom) 10

\footnotetext{
${ }^{23}$ The Herfindahl index is defined as $\operatorname{Herfindahl}_{j}=\sum_{i=1}^{I} S_{i j}{ }^{2}$, where $S_{i j}$ is the market share of firm $i$ in industry $j$ in terms of net sales in each sample year.

${ }^{24}$ The data for analyst coverage is extracted from the Bloomberg database. The sample period is from 1997 to 2011. We also use the aggregated number of analysts at the industry level to define high and low analyst coverage industries. The results are similar to those produced when using the number of analysts per firm in a given industry.
} 
industries as high (low) analyst coverage industries from July of this year to June of the next. We run the Fama-MacBeth regressions for the high and low analyst coverage industries separately. Panel D shows that, in high analyst coverage industries, industry contrarian performance is virtually zero. However, in low analyst coverage industries, losing industries significantly outperform winning industries. These findings highlight the role of financial analysts in improving information dissemination and are also consistent with the mispricing explanation of industry contrarian performance.

Overall, we show that the contrarian spreads are only significant in industries with high valuation uncertainty and these findings are robust to various risk-adjustment techniques and are not affected by the seasonal patterns.

\section{Conclusions}

This study investigates the role of past industry performance in driving long-term return reversals in the UK market. We find a strong industry influence on stock return reversals when we condition industry returns on past performance. We also find that firms in losing industries significantly outperform those in winning industries over the subsequent five years. These industry reversals remain strong and persistent after controlling for stock and industry momentum, seasonal effects and traditional risk factors. We also compare these industry reversals with the stock reversals generated from individual stocks' past performance. We find that stock reversals come exclusively in January and April, consistent with the tax loss selling hypothesis. However, the absence of seasonal patterns in industry reversals does not support the tax-based explanation. Further analysis suggests that past industry performance is the main determinant of stock reversals. However, past stock performance cannot explain industry reversals. The overall results suggest that past industry performance contains salient information about long-term stock returns. Next, we investigate whether industry reversals are driven by risk or are a result of mispricing. In contrast to the risk-based explanation, we show that industry contrarian performance appears in both good and bad states of the economy. Consistent with the mispricing view, we also find that industry contrarian performance is greater in industries with high valuation uncertainty.

Our results have several important implications. First, we show that industries play an important role in conditional asset pricing. Specifically, while previous studies show that contemporaneous industry returns have a negligible impact on stock returns (e.g., Fama and French, 1997; Heston and Rouwenhorst, 1994; Griffin and Karolyi, 1998), we find past industry performance to affect future stock returns. Second, we contribute to the debate on 
the causes of contrarian profits by showing that industry reversals are the main determinant of stock reversals and are more likely to represent mispricing than risk. Finally, our results suggest that investors are better off exploiting contrarian strategies by focusing on past industry performance. 


\section{References}

Admati, A. R. 1985, A noisy rational expectations equilibrium for multi-asset securities markets, Econometrica, 53, 629-658

Ali, A., Klasa, S. and Yeung, E. 2014, Industry concentration and corporate disclosure policy, Journal of Accounting and economics, 58, 240-264

Amihud, Y. 2002, Illiquidity and stock returns: cross-section and time-series effects, Journal of Financial Markets, 5, 31-56

Balakrishnan, K., Bartov, E. and Faurel, L., 2010, Post loss/profit announcement drift., Journal of Accounting and Economics 50, 20-41.

Ball, R. and Kothari, S. P. 1989, Nonstationary expected returns: implications for tests of market efficiency and serial correlation in returns, Journal of Financial Economics, 25, 51-74

Barberis, N., A. Shelifer and R. Vishny, 1998, A model of investor sentiment, Journal of Financial Economics, 49, 307-343

Barth , M.E., R. Kasznik, and M.F. McNichos, 2001, Analyst coverage and intangible assets, Journal of Accounting Research, 39, 1-34

Berk, J., R. Green, and V. Naik, 1999, Optimal investment, growth options and security returns. Journal of Finance, 54, 1153-1607

Bhushan, R. 1989, Firm characteristics and analyst following, Journal of Accounting and Economics, 11, 255-274

Botosan, C.A. and Stanford, M., 2005, Managers' motives to withhold segment disclosures and the effect of SFAS No. 131 on analysts' information environment, The Accounting Review, 80, 751-772

Boutchkova, M., Doshi, H, Durner A. and Molchanov, A, 2012, Precarious politics and return volatility, Review of Financial Studies, 25, 1111-1154

Brennan, M., Chordia, T. and Subrahmanyam, A., 1998, Alternative factor specifications, security characteristics, and the cross-section of expected stock returns, Journal of Financial Economics, 345-373

Bustamante, M.D. 2015, Strategic investment and industry risk dynamics, Review of Financial Studies, 28, 297-341

Carlson, M., A. Fisher and R. Giammarino. 2004, Corporate investment and asset price dynamics: Implications for the cross-section of returns. Journal of Finance, 59, 2577-2603.

Carlson, M., E. Dockner, A. Fisher and R. Giammarino, 2014, Leaders, followers, and risk dynamics in industry equilibrium, Journal of Financial and Quantitative Analysis, forthcoming 
Chan, K. and Hameed, A. 2006, Stock prices synchronicity and analyst coverage in emerging markets, Journal of Financial Economics, 80, 115-147

Chou, P.H., K.C.J. Wei, and H. Chung, 2007, Sources of contrarian profits in the Japanese stock market, Journal of Empirical Finance 14, 261-286

Clare, A. and S. Thomas, 1995. The overreaction hypothesis and the UK stock market, Journal of Business Finance and Accounting 22, 961-972.

Cohen, R., and C. Polk, 1996. An investigation of the impact of industry factors in asset pricing tests. Working Paper.

Cohen, R., C. Polk, and T. Vuolteenaho, 2003, The value spread. Journal of Finance 58, 609641

Daniel, K., D. Hirshleifer, and A. Subrahmanyam, 1998, Investor psychology and security market under-and overreactions, Journal of Finance, 53, 1839-1885

Das, C. Levine, and Sivaramakrishnan, K. 1998, Earnings predictability and bias in analysts' earnings forecasts, The Accounting Review, 73, 277-294

DeBondt, W. and R. Thaler, 1985, Does the stock market overreact? Journal of Finance, 40, 793-805

DeBont, W. and R. Thaler, 1987, Further evidence on investor overreaction and stock market seasonality, Journal of Finance, 42, 557-581

Dhaliwal, D. S., O. Z. Li, A. Tsang and Y. G. Yang. 2011, Voluntary Nonfinancial Disclosure and the Cost of Equity Capital: The Initiation of Corporate Social Responsibility Reporting, The Accounting Review, 86, 59-100

Fama, E. 1976, Foundation of Finance: Portfolio Decisions and Securities Prices, Basic Books, Inc., New York

Fama, E. and J. MacBeth, 1973, Risk, return and equilibrium: Empirical tests, Journal of Political Economy, 81, 607-636

Fama, E. and K. R. French, 1993, Common risk factors in the returns on stocks and bonds, Journal of Financial Economics, 33, 3-56

Fama, E. and K. R. French, 1995, Size and book-to-market factors in earnings and returns, Journal of Finance, 50, 131-155

Fama, E. and K. R. French, 1996, Multifactor explanations of asset pricing anomalies, Journal of Finance, 51, 55-84

Fama, E. and K. R. French, 1997, Industry cost of equity, Journal of Financial Economics, 43, 153-193 
Fama, E. and K. R. French, 2006, Profitability, investment, and average returns, Journal of Financial Economics, 82, 491-518

Fama, E. and K. R. French, 2008, Dissecting anomalies, Journal of Finance, 63, 1653-1678

Fama, E. and K. R. French, 2015, A five-factor model, Journal of Financial Economics, forthcoming

Gal-Or, E., 1985. Information sharing in oligopoly. Econometrica, 53, 329-343.

Gaspar, J.M. and M. Massa, 2006, Idiosyncratic volatility and product market competition, Journal of Business, 79, 3125-3252

George, T. and C. Hwang, 2004, The 52-week high and momentum investing, Journal of Finance, 59, 2145-2176

George, T. and C. Hwang, 2007, Long-term return reversals: Overreaction or taxes? Journal of Finance, 62, 2866-2896

Gregory, A., R. Tharayan, and A. Christidis, 2013, Constructing and testing alternative versions of the Fama-French and Carhart Models in the UK, Journal of Business Accounting and Finance, 40, 172-214

Griffin, J. and Karolyi, A., 1998, Another look at the role of the industrial structure of markets for international diversification strategies, 50, 351-373

Griffin, J., P. Kelly and F. Nardari, 2010, Do market efficiency measures yield correct inferences? A comparison of developed and emerging markets, Review of Financial Studies, $23,3225-3277$

Grinblatt, M. and T. Moskowitz, 2004, Predicting stock price movement from past returns: The role of consistency and tax loss selling, Journal of Financial Economics, 71, 541-579

Grossman, S. and Stiglitz, J. 1980, On the impossibility of informationally efficient markets, The American Economic Review, 70, 393-408

Hameed, A. and G. M. Mian, 2015, Industries and stock return reversals, Journal of Financial and Quantitative Analysis, 50, 89-117

Heston, S. L. and Rouwenhorst, K.G, 1994, Does industrial structure explain the benefits of international diversification? Journal of Financial Economics, 36, 3-27

Hirshleifer, D., Hou, K and Teoh, S. H., 2012, The accrual anomaly: risk or mispricing? Management Science, 58, 320-335

Hirshleifer, D., Hsu, P-H and Li, D., 2013, Innovative efficiency and stock returns, Journal of Financial Economics, 107, 632-654

Hirshleifer, D., Lim, S. and Teoh, S.H., 2009. Driven to distraction: extraneous events and underreaction to earnings news, Journal of Finance 63, 2287-2323 
Hirshleifer, D., Lim, S. and Teoh, S.H., 2011, Limited investor attention and stock market misreactions to accounting information, Review of Asset Pricing Studies, 1, 35-73.

Hong, H. and J. Stein, 1999, A unified theory of underreaction, momentum trading and overreaction in asset markets, Journal of Finance, 54, 2143-2184

Hong, H., Lim, T. and Stein, C. J. 2000, Bad news travels slowly: size, analyst coverage, and the profitability of momentum strategies, Journal of Finance, 55, 265-295

Hong, H., W. Torous and R. Valkanov, 2007, Do industry lead stock markets? Journal of Financial Economics, 83, 367-396

Hou, K. , 2007, Industry information diffusion and the lead-lag effect in stock returns, Review of Financial Studies, 20, 1113-1138

Hou, K. and D. T. Robinson, 2006, Industry concentration and average stock returns, Journal of Finance, 61, 1927-1956

Hou,K., C.Xue and L. Zhang, 2015, Digesting anomalies: an investment approach, Review of Financial Studies, forthcoming

Ince, O. and R. Porter, 2006, Individual equity return data from Thomson Datastream: handle with care, Journal of Financial Research, 29, 463-479

Irvine, P.J. and J. Pontiff, 2009, Idiosyncratic return volatility, cash flows, and product market competition, Review of Financial Studies, 22, 1149-1177

Jegadeesh, N. 1990, Evidence of predictable behaviour in security prices, Journal of Finance, $45,881-898$

Jegadeesh, N. and S. Titman, 1993, Returns to buying winners and selling losers: Implications for market efficiency, Journal of Finance, 48, 65-91

Jegadeesh, N. and S. Titman, 2001, Profitability of momentum strategies: an evaluation of alternative explanations, Journal of Finance, 2001, 56, 699-720

Kelly, P., 2014, Information Efficiency and Firm-specific Return Variation, the Quarterly Journal of Finance, 4, 145-189

Klein, P., 2001, The capital gains lock-in effect and long-horizon return reversals, Journal of Financial Economics, 59, 33-62

Kogan, Leonid, 2001, An equilibrium model of irreversible investment, Journal of Financial Economics, 62, 201-245.

Krishnaswami, S. and Subramaniam, V., 1999, Information asymmetry, valuation, and the corporate spin-off decision, Journal of Financial Economics, 53, 73-112

Kross, W., Ro, B. and Schroeder, D. 1990, Earnings expectations: the analysts' information advantage, The Accounting Review, 65, 461-476 
Kumar, A., 2009, Who gambles in the stock market?, Journal of Finance, 64, 1889-1993

Lakonishok, J., A. Shleifer, and R.W. Vishny, 1992. The impact of institutional trading on stock price, Journal of Financial Economics 32, 23-43

Lakonishok, J., A. Shleifer, and R.W. Vishny, 1994. Contrarian investment, extrapolation and risk, Journal of Finance 49, 1541-1578

Lam, E. F. Y. and Wei, J.K.C., 2011, Limits-to-arbitrage, investment frictions, and the asset growth anomaly, Journal of Financial Economics, 102, 127-149

Lehmann, B. N., 1990, Fads, martingales, and market efficiency, Quarterly Journal of Economics, 60, 1-28

Lewellen, J., Nagel S, and Shanken J.A. 2010, A sceptical appraisal of asset-pricing tests, Journal of Financial Economics, 96, 175-194

Liu, W, 2006, A liquidity augmented capital asset pricing model, Journal of Financial Economics, 82, 631-671

MacKinlay, A. C., 1995, Multifactor models do not explain deviations from the CAPM, Journal of Financial Economics, 38, 3-28

Mashruwala, C., Rajgopal, S. and Shevlin T., 2006, Why is the accrual anomaly not arbitraged away? The role of idiosyncratic risk and transaction costs, Journal of Accounting Economics, 42, 3-33

Merton, R.C., 1987, A simple model of capital market equilibrium with incomplete information, Journal of Finance, 42, 483-510

Moskowitz, T. J. and M. Grinblatt, 1999, Do industry explain momentum?, Journal of Finance, 54, 1249-1290

Newey, W. and K. West, 1987, A simple, positive semi-definite, heteroscedastic and autocorrelation consistent covariance matrix, Econometrica, 55, 703-708

Ng. L. and Wang, Q. 2004, Institutional trading and the turn-of-the-year effect, Journal of Financial Economics, 343-366

Novy-Marx, R., 2013, The other side of value: the gross profitability premium, Journal of Financial Economics, 108, 1-28

Piotroski, J. and D. Doulstone, 2004, The influence of analysts, institutional investors, and insiders on the incorporation of market, industry, and firm-specific information into stock prices, The Accounting Review, 79, 1119-1151

Preress, J. 2010, Product market competition, insider trading, and stock market efficiency, Journal of Finance, 65, 1-43

Shleifer, A and Vishny, R. W. 1997, The limits of arbitrage, Journal of Finance, 52, 35-55 
Shumway, T. 1997, The delisting bias in CRSP data, Journal of Finance, 52, 327-340

Sias, R. and Starks, L., 1997, Return autocorrelation and institutional investors, Journal of Financial Economics, 46, 103-131

Sloan, R. 1996, Do stock prices fully reflect information in accruals and cash flows about future earnings, The Accounting Review, 71, 289-316

Stambaugh, R. F., Yu, J. and Yuan, Y., 2015, Arbitrage asymmetry and the idiosyncratic volatility puzzle, Journal of Finance, 70, 1903-1948

Welch, I., 2004, Capital structure and stock returns, Journal of Political Economy, 112, 106131

West, K.1988 , Dividend innovations and stock price volatility, Econometrica, 56, 37-61

$\mathrm{Wu}, \mathrm{Y}$. and Y. Li, 2011, Long-term return reversals-value and growth or tax? UK evidence, Journal of International Financial Institutions, Markets, and Money, 21, 347-368

Zhang, L., 2005, The value premium, Journal of Finance, 60, 67-103 
Table 1 Description and summary statistics of industry

The table reports basic characteristics of the 20 super-sector based industry portfolios according to the International Classification of Benchmarks (ICB). The 20 industries are formed monthly from January 1975 to December 2011. The average number of stocks included in each industry is reported. The average percentage of total market capitalisations, five-year raw returns, and five-year excess market returns are the time-series means of cross-sectional industry averages in each month. Five-year raw returns are calculated from five-year valueweighted industry return indexes and five-year excess market returns are calculated from five-year industries' raw returns minus five-year FTSE All Share market index returns. The last row average is reported the times series means for the statistics across 20 industries in each month.

\begin{tabular}{llcccc}
$\begin{array}{c}\text { Industry } \\
\text { code }\end{array}$ & \multicolumn{1}{c}{ Industry Name } & $\begin{array}{c}\text { Avg. No. } \\
\text { of Stocks }\end{array}$ & $\begin{array}{c}\text { Avg. \% of } \\
\text { Market Cap. }\end{array}$ & $\begin{array}{c}\text { 5-year Raw } \\
\text { Return }\end{array}$ & $\begin{array}{c}\text { 5-year Excess } \\
\text { Market Return }\end{array}$ \\
\hline 1 & Oil \& Gas & 43 & $8.48 \%$ & 0.7220 & 0.1594 \\
2 & Chemicals & 40 & $3.21 \%$ & 0.5103 & -0.0512 \\
3 & Basic Resources & 51 & $2.99 \%$ & 0.5454 & -0.0200 \\
4 & Constructions \& Materials & 54 & $2.18 \%$ & 0.4859 & -0.0748 \\
5 & Industrial Goods \& Services & 364 & $7.68 \%$ & 0.1853 & -0.3768 \\
6 & Automibles \& Parts & 6 & $0.79 \%$ & 0.0924 & -0.4699 \\
7 & Food \& Beverage & 70 & $5.07 \%$ & 0.6780 & 0.1169 \\
8 & Personal \& Household Goods & 138 & $3.58 \%$ & 0.7781 & 0.2163 \\
9 & Health Care & 50 & $5.27 \%$ & 0.9026 & 0.3389 \\
10 & Retail & 137 & $5.56 \%$ & 0.5772 & 0.0155 \\
11 & Media & 86 & $4.12 \%$ & 0.4488 & -0.1123 \\
12 & Travel \& Leisure & 90 & $2.65 \%$ & 0.4998 & -0.0622 \\
13 & Telecommuincations & 18 & $6.67 \%$ & 1.2969 & 0.7309 \\
14 & Utilities & 31 & $4.14 \%$ & 0.5856 & 0.2063 \\
15 & Banks & 26 & $20.03 \%$ & 0.4146 & -0.1467 \\
16 & Insurance & 38 & $8.77 \%$ & 0.5106 & -0.0505 \\
17 & Financial Services & 90 & $2.31 \%$ & 0.6368 & 0.0738 \\
18 & Technology & 83 & $0.99 \%$ & 0.2801 & -0.2832 \\
19 & Real Estate & 95 & $1.92 \%$ & 0.5202 & -0.0425 \\
20 & Others & 96 & $3.50 \%$ & 0.2414 & -0.4879 \\
& Average & 98 & $6.70 \%$ & 0.5418 & -0.0135 \\
\hline
\end{tabular}


Table 2 Correlation matrix for long term reversal variables

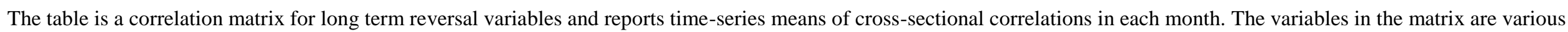

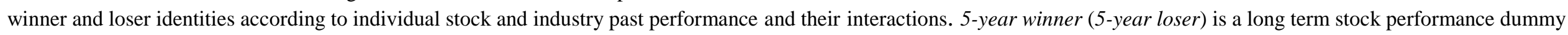

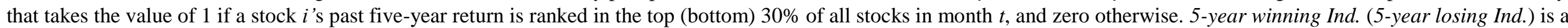

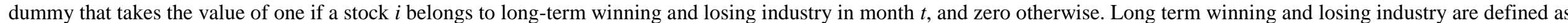

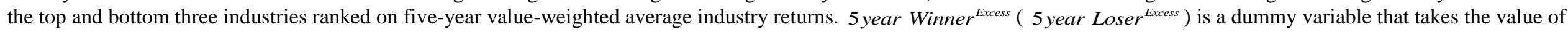

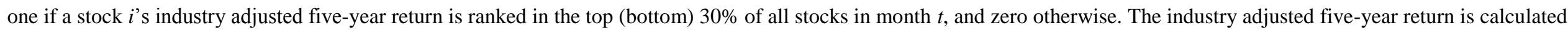

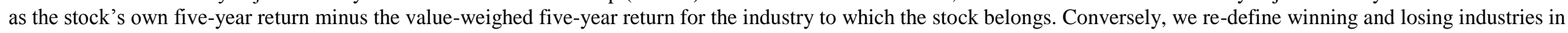

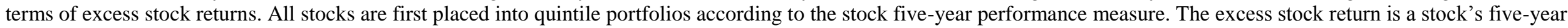

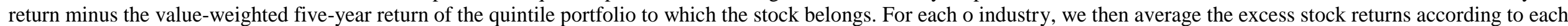

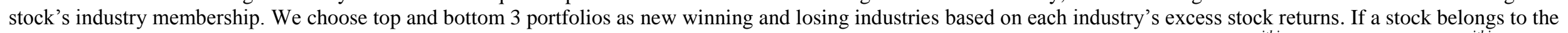

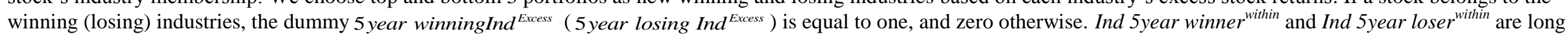

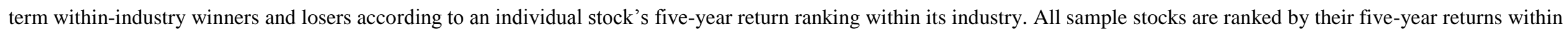
each industry in terms of their industry memberships. The top (bottom) $30 \%$ of stocks in a given industry is labelled as within-industry winners (losers).

\begin{tabular}{|c|c|c|c|c|c|c|c|c|c|c|}
\hline & $\begin{array}{l}\text { 5-year } \\
\text { winner }\end{array}$ & 5-year loser & $\begin{array}{l}5 \text {-year } \\
\text { winning Ind }\end{array}$ & $\begin{array}{l}\text { 5-year losing } \\
\text { Ind }\end{array}$ & $\begin{array}{l}\text { 5-year } \\
\text { winner }^{\text {Excess }}\end{array}$ & $\begin{array}{l}\text { 5-year } \\
\text { loser }^{\text {Excess }}\end{array}$ & $\begin{array}{l}\text { 5year winning } \\
\text { Ind }^{\text {Excess }}\end{array}$ & $\begin{array}{l}\text { 5year losing } \\
\text { Ind }^{\text {Excess }}\end{array}$ & $\begin{array}{l}\text { Ind.5year } \\
\text { winner }^{\text {within }}\end{array}$ & $\begin{array}{l}\text { Ind.5year } \\
\text { loser }^{\text {within }}\end{array}$ \\
\hline 5-year winner & 1 & & & & & & & & & \\
\hline 5-year loser & -0.4279 & 1 & & & & & & & & \\
\hline 5-year winning Ind & 0.1754 & -0.1467 & 1 & & & & & & & \\
\hline 5-year losing Ind & -0.1743 & 0.1651 & -0.1845 & 1 & & & & & & \\
\hline 5-year winner ${ }^{\text {Excess }}$ & 0.7932 & -0.4272 & -0.1437 & 0.0505 & 1 & & & & & \\
\hline 5-year loser ${ }^{\text {Excess }}$ & -0.4202 & 0.7229 & 0.1329 & -0.2312 & -0.4282 & 1 & & & & \\
\hline $5 y e a r$ winning Ind ${ }^{\text {Excess }}$ & 0.1059 & -0.1245 & 0.0977 & -0.1158 & 0.1238 & -0.0343 & 1 & & & \\
\hline 5year losing Ind ${ }^{\text {Excess }}$ & -0.1130 & 0.1268 & -0.0815 & 0.1736 & -0.1179 & 0.0539 & -0.1278 & 1 & & \\
\hline Ind.5year winner ${ }^{\text {within }}$ & 0.7909 & -0.0550 & -0.0129 & 0.0054 & 0.3020 & -0.2908 & -0.0779 & 0.0847 & 1 & \\
\hline Ind.5year loser ${ }^{\text {within }}$ & -0.0559 & 0.7862 & -0.0108 & 0.0063 & -0.2866 & 0.2952 & 0.1523 & -0.0843 & -0.2933 & 1 \\
\hline
\end{tabular}


Table 3 Identifying industry reversals

We estimate $60(j=1, \ldots, 60)$ cross-sectional regressions on a monthly basis between February 1980 and December 2011 as following

$R_{i t}=b_{0 j t}+b_{1 j t} R_{i, t-1}+b_{2 j t}$ size $_{i, t-1}+b_{3 j t}$ BM $_{i, t-1}+b_{4 j t} 52 w k h$ Winner $_{i, t-j}+b_{5 j t} 52 w_{k h L o s e r}, t-j+b_{6 j t}$ IndMomWinner $_{i, t-j}+b_{7 j t}$ IndMomLoser $_{i, t-j}$

$+b_{8 j t}$ 5yearWinner $_{i, t-j}+b_{9 j t}$ 5yearLoser $_{i, t-j}+b_{10 j t}$ 5yearWinningInd $_{i, t-j}+b_{11 j t}$ 5yearLosingInd $_{i, t-j}+e_{i j t}$

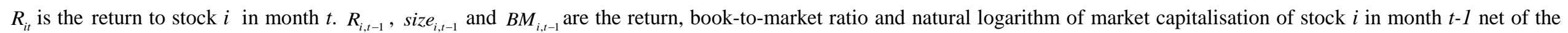

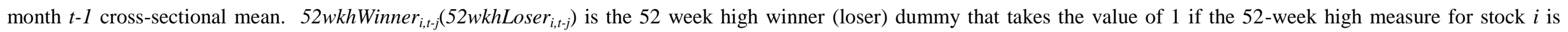

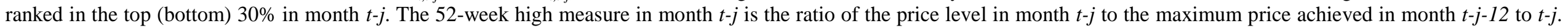

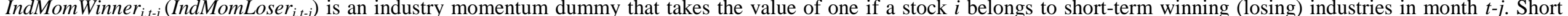

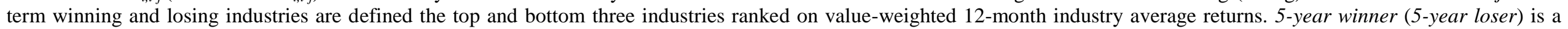

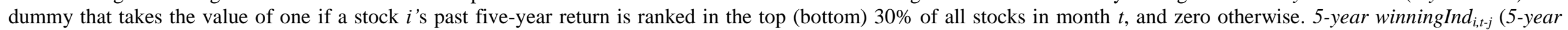

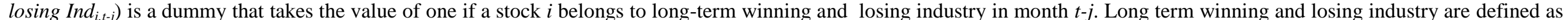

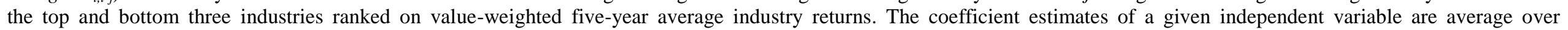

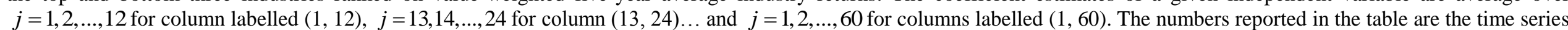

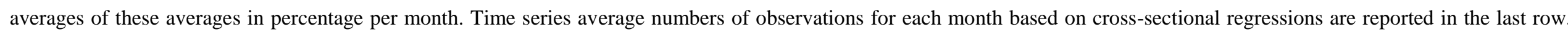
Newey-West (1987) adjusted $t$-statistics are reported in parentheses.

\begin{tabular}{|c|c|c|c|c|c|c|c|c|c|c|c|c|}
\hline & (1) & (2) & (3) & (4) & (5) & (6) & (7) & (8) & (9) & (10) & (11) & (12) \\
\hline & $\begin{array}{l}\text { Monthly } \\
\text { return } \\
(1,12)\end{array}$ & $\begin{array}{l}\text { Monthly } \\
\text { return }(1,12) \\
\text { Jan \& Apr } \\
\text { Excl. }\end{array}$ & $\begin{array}{l}\text { Monthly } \\
\text { return } \\
(13,24)\end{array}$ & $\begin{array}{l}\text { Monthly } \\
\text { return }(13,24) \\
\text { Jan \& Apr } \\
\text { Excl. }\end{array}$ & $\begin{array}{l}\text { Monthly } \\
\text { return } \\
(25,36)\end{array}$ & $\begin{array}{l}\text { Monthly } \\
\text { return }(25,36) \\
\text { Jan \& Apr } \\
\text { Excl. }\end{array}$ & $\begin{array}{l}\text { Monthly } \\
\text { return } \\
(37,48)\end{array}$ & $\begin{array}{l}\text { Monthly } \\
\text { return } \\
(37,48) \text { Jan \& } \\
\text { Apr Excl. }\end{array}$ & $\begin{array}{l}\text { Monthly } \\
\text { return } \\
(49,60)\end{array}$ & $\begin{array}{l}\text { Monthly } \\
\text { return }(49,60) \\
\text { Jan \& Apr } \\
\text { Excl. }\end{array}$ & $\begin{array}{l}\text { Monthly } \\
\text { return } \\
(1,60)\end{array}$ & $\begin{array}{l}\text { Monthly } \\
\text { return }(1,60) \\
\text { Jan \& Apr } \\
\text { Excl. }\end{array}$ \\
\hline \multirow[t]{2}{*}{ Intercept } & 0.78 & 0.54 & 0.68 & 0.45 & 0.70 & 0.49 & 0.75 & 0.41 & 0.78 & 0.46 & 0.73 & 0.47 \\
\hline & (2.94) & $(2.54)$ & $(3.54)$ & (1.96) & $(2.91)$ & (1.95) & $(2.76)$ & (1.88) & $(2.89)$ & (1.78) & (2.94) & $(1.82)$ \\
\hline \multirow[t]{2}{*}{$R_{i, t-1}$} & -1.21 & -0.83 & -1.18 & -0.97 & -1.27 & -1.00 & -1.05 & -0.79 & -1.10 & -0.73 & -1.16 & -0.87 \\
\hline & $(-2.69)$ & $(-1.89)$ & $(-2.54)$ & $(-2.47)$ & $(-2.76)$ & $(-2.17)$ & $(-2.43)$ & $(-1.83)$ & $(-2.69)$ & $(-2.54)$ & $(-3.49)$ & $(-2.67)$ \\
\hline \multirow[t]{2}{*}{ Size $_{i, t-1}$} & -0.02 & -0.01 & -0.04 & -0.02 & -0.06 & -0.03 & -0.05 & -0.03 & -0.05 & -0.03 & -0.03 & -0.02 \\
\hline & $(-1.66)$ & $(-1.67)$ & $(-2.23)$ & $(-1.79)$ & $(-2.18)$ & $(-1.78)$ & $(-1.88)$ & $(-1.60)$ & $(-2.20)$ & $(-1.87)$ & $(-2.52)$ & $(-2.00)$ \\
\hline \multirow[t]{2}{*}{$B M_{i, t-1}$} & 0.28 & 0.31 & 0.28 & 0.30 & 0.27 & 0.30 & 0.26 & 0.30 & 0.26 & 0.29 & 0.27 & 0.30 \\
\hline & (5.94) & $(5.79)$ & $(5.88)$ & $(5.72)$ & $(5.73)$ & $(5.58)$ & $(5.37)$ & $(5.25)$ & $(5.22)$ & $(5.09)$ & $(5.65)$ & $(5.51)$ \\
\hline
\end{tabular}




\begin{tabular}{|c|c|c|c|c|c|c|c|c|c|c|c|c|}
\hline & $(1)$ & (2) & (3) & (4) & (5) & (6) & (7) & (8) & (9) & (10) & $(11)$ & (12) \\
\hline & $\begin{array}{l}\text { Monthly } \\
\text { return } \\
(1,12)\end{array}$ & $\begin{array}{l}\text { Monthly } \\
\text { return }(1,12) \\
\text { Jan \& Apr } \\
\text { Excl. }\end{array}$ & $\begin{array}{l}\text { Monthly } \\
\text { return } \\
(13,24)\end{array}$ & $\begin{array}{l}\text { Monthly } \\
\text { return } \\
(13,24) \text { Jan } \\
\text { \& Apr Excl. }\end{array}$ & $\begin{array}{l}\text { Monthly } \\
\text { return } \\
(25,36)\end{array}$ & $\begin{array}{l}\text { Monthly } \\
\text { return } \\
(25,36) \text { Jan } \\
\text { \& Apr Excl. }\end{array}$ & $\begin{array}{l}\text { Monthly } \\
\text { return } \\
(37,48)\end{array}$ & $\begin{array}{l}\text { Monthly } \\
\text { return } \\
(37,48) \text { Jan } \\
\& \text { Apr Excl. }\end{array}$ & $\begin{array}{l}\text { Monthly } \\
\text { return } \\
(49,60)\end{array}$ & $\begin{array}{l}\text { Monthly } \\
\text { return } \\
(49,60) \text { Jan } \\
\text { \& Apr Excl. }\end{array}$ & $\begin{array}{l}\text { Monthly } \\
\text { return } \\
(1,60)\end{array}$ & $\begin{array}{l}\text { Monthly } \\
\text { return }(1,60) \\
\text { Jan \& Apr } \\
\text { Excl. }\end{array}$ \\
\hline \multirow[t]{2}{*}{ 52week high winner } & 0.46 & 0.54 & 0.03 & 0.10 & -0.00 & 0.05 & 0.04 & 0.09 & -0.01 & 0.00 & 0.10 & 0.15 \\
\hline & $(5.94)$ & (7.17) & $(0.74)$ & $(2.00)$ & $(-0.10)$ & $(1.25)$ & $(1.39)$ & $(2.58)$ & $(-0.61)$ & $(0.23)$ & $(3.51)$ & $(3.16)$ \\
\hline \multirow[t]{2}{*}{ 52week high loser } & -1.05 & -1.16 & -0.27 & -0.43 & -0.26 & -0.36 & -0.25 & -0.31 & -0.16 & -0.20 & -0.39 & -0.49 \\
\hline & $(-7.68)$ & $(-8.71)$ & $(-3.11)$ & $(-4.60)$ & $(-3.22)$ & $(-4.27)$ & $(-3.57)$ & $(-4.03)$ & $(-2.49)$ & $(-2.89)$ & $(-5.57)$ & $(-6.72)$ \\
\hline \multirow[t]{2}{*}{ Ind_mom_winner } & 0.15 & 0.05 & -0.00 & 0.05 & -0.12 & -0.08 & -0.06 & -0.03 & 0.03 & 0.07 & -0.03 & 0.02 \\
\hline & $(1.93)$ & $(0.75)$ & $(-0.13)$ & $(0.49)$ & $(-1.38)$ & $(-0.80)$ & $(-0.77)$ & $(-0.39)$ & $(0.29)$ & $(0.59)$ & $(-0.57)$ & $(0.23)$ \\
\hline \multirow[t]{2}{*}{ Ind_mom_loser } & -0.18 & -0.14 & 0.07 & 0.05 & -0.11 & -0.10 & -0.00 & 0.03 & -0.01 & 0.03 & -0.05 & -0.03 \\
\hline & $(-2.00)$ & $(-1.44)$ & $(0.91)$ & $(0.52)$ & $(-1.47)$ & $(-1.19)$ & $(-0.07)$ & $(0.30)$ & $(-0.09)$ & $(0.31)$ & $(-1.04)$ & $(-0.57)$ \\
\hline \multirow[t]{2}{*}{ 5-year winner } & -0.04 & 0.02 & -0.01 & 0.00 & -0.02 & -0.01 & 0.01 & 0.03 & -0.01 & -0.01 & -0.01 & 0.00 \\
\hline & $(-0.79)$ & $(0.43)$ & $(-0.25)$ & $(0.13)$ & $(-0.44)$ & $(-0.19)$ & $(0.15)$ & $(0.47)$ & $(-1.22)$ & $(-0.40)$ & $(-0.40)$ & $(0.15)$ \\
\hline \multirow[t]{2}{*}{ 5-year loser } & 0.07 & -0.07 & 0.11 & 0.02 & 0.12 & 0.07 & 0.16 & 0.10 & 0.10 & 0.06 & 0.11 & 0.04 \\
\hline & $(0.79)$ & $(-0.89)$ & $(1.80)$ & $(0.29)$ & $(1.83)$ & $(0.96)$ & $(2.24)$ & $(1.34)$ & $(1.59)$ & $(0.93)$ & $(2.07)$ & $(0.78)$ \\
\hline \multirow[t]{2}{*}{ 5-year winning Ind } & -0.09 & 0.01 & -0.04 & -0.02 & 0.06 & 0.06 & 0.08 & 0.09 & -0.13 & -0.12 & -0.02 & 0.02 \\
\hline & $(-0.88)$ & $(0.13)$ & $(-0.98)$ & $(-1.00)$ & $(1.01)$ & $(0.95)$ & $(0.76)$ & $(0.80)$ & $(-1.29)$ & $(-1.21)$ & $(-0.09)$ & $(0.26)$ \\
\hline \multirow[t]{2}{*}{ 5-year losing Ind } & 0.06 & 0.08 & 0.17 & 0.22 & 0.32 & 0.32 & 0.37 & 0.40 & 0.45 & 0.49 & 0.27 & 0.30 \\
\hline & $(0.71)$ & $(0.89)$ & $(1.88)$ & $(2.20)$ & $(3.43)$ & $(3.33)$ & $(3.91)$ & $(3.79)$ & $(4.30)$ & $(4.26)$ & $(3.86)$ & $(3.90)$ \\
\hline 5-year loser- & 0.10 & -0.10 & 0.12 & 0.01 & 0.13 & 0.08 & 0.15 & 0.07 & 0.11 & 0.08 & 0.12 & 0.04 \\
\hline 5-year winner & $(1.24)$ & $(-0.94)$ & $(1.68)$ & $(0.15)$ & $(1.76)$ & $(0.88)$ & $(1.90)$ & $(0.98)$ & $(1.47)$ & $(0.95)$ & $(1.96)$ & $(0.56)$ \\
\hline 5-year losing Ind- & 0.15 & 0.07 & 0.21 & 0.23 & 0.26 & 0.27 & 0.29 & 0.31 & 0.57 & 0.60 & 0.29 & 0.29 \\
\hline 5-year winning Ind & $(1.42)$ & $(0.48)$ & $(1.75)$ & $(1.85)$ & $(2.01)$ & (1.99) & $(2.45)$ & $(2.50)$ & $(3.81)$ & $(3.56)$ & (2.69) & $(2.51)$ \\
\hline Avg. obs & 1439 & & 1330 & & 1269 & & 1204 & & 1137 & & 1265 & \\
\hline
\end{tabular}


Table 4 Nesting comparisons between stock and industry reversals

We estimate $60(j=1, \ldots, 60)$ cross-sectional regressions on a monthly basis between February 1980 and December 2011 as following for Panel A

$R_{i t}=b_{0 j t}+b_{1 j t} R_{i, t-1}+b_{2 j t}$ size $_{i, t-1}+b_{3 j t}$ BM $_{i, t-1}+b_{4 j t} 52 w k h$ Winner $_{i, t-j}+b_{5 j t} 52 w k h$ Loser $_{i, t-j}+b_{6 j t}$ IndMomWinner $_{i, t-j}+b_{7 j t}$ IndMomLoser $_{i, t-j}$

$+b_{8 j t}$ 5yearWinner $_{i, t-j}+b_{9 j t}$ 5yearLoser $_{i, t-j}+b_{10 j t}$ Neutral $_{l_{i, t-j}}^{\text {Stok }} \times 5$ yearWinningInd $d_{i, t-j}+b_{11 j t}$ Neutral $_{i, t-j}^{\text {stock }} \times 5$ yearLosingInd ${ }_{i, t-j}+e_{i j t}$

The following equation is estimated for Panel B

$R_{i t}=b_{0 j t}+b_{1 j t} R_{i, t-1}+b_{2 j t}$ size $_{i, t-1}+b_{3 j t} B_{i, t-1}+b_{4 j t} 52 w_{k h W i n n e r} r_{i, t-j}+b_{5 j t} 52 w$ whLoser $_{i, t-j}+b_{6 j t}$ IndMomWinner $_{i, t-j}+b_{7 j t}$ IndMomLoser $_{i, t-j}+b_{8 j t} 5$ yearWinningInd ${ }_{i, t-j}$

$+b_{9, j t}$ 5yearLosingInd $_{i, t-j}+b_{10 j t}$ Neutral $_{i, t, j}^{\text {indsty }} \times 5$ yearWinnner $r_{i, t-j}+b_{11, j t}{\text { Neutral } l_{i, t-j}^{\text {industy }} \times 5 \text { yearLoser }}_{i, t-j}+e_{i j t}$

$R_{i t}$ is the return to stock $i$ in month $t . R_{i, t-1}, B M_{i, t-1}$ and $s i z e_{i, t-1}$ are the return, book-to-market ratio and natural logarithm of market capitalisation of stock $i$ in month $t-1$ net of the month $t-1$ cross-sectional mean. $52 w k h$ Winner $_{i, t-j}\left(52 w k h\right.$ Loser $\left._{i, t-j}\right)$ is the 52 week high winner (loser) dummy that takes the value of one if the 52 -week high measure for stock $i$ is ranked in the top (bottom) $30 \%$ in month $t-j$, and zero otherwise. The 52 -week high measure in month $t-j$ is the ratio of the price level in month $t-j$ to the maximum price achieved in month $t-j-12$ to $t-j$. IndMomWinner $r_{i, t-j}\left(\right.$ IndMomLoser $_{i, t-j}$ ) is a dummy that takes the value of one if a stock $i$ belongs to short-term winning (losing) industries in month $t-j$, and zero otherwise. Short term winning and losing industries are defined the top and bottom 3 industries ranked on 12 -month value-weighted average industry returns. 5 -year winner ${ }_{i, t-j}(5-$ year loser $_{i, t-j}$ ) is a dummy that takes the value of one if a stock $i$ 's past five-year return is ranked in the top (bottom) $30 \%$ of all stocks in month $t-j$, and zero otherwise. Neutral $l_{i, t-j}^{\text {stock }}$ is a dummy variable that takes the value of one if a stock $i$ is neither five-year losers nor five-year winners in month $t-j$, and zero otherwise. Neutral $l_{i, t-j}^{\text {indsty }}$ is a dummy variable that takes value of one if a stock $i$ belongs to neither winning nor losing industries according to five-year value-weighted industry returns, and zero otherwise. 5 -year winning Ind ${ }_{i, t-j}$ ( 5 year losing $\left.I n d_{i, t-j}\right)$ is a dummy that takes the value of one if a stock $i$ belongs to long-term winning and losing industry in month $t-j$, and zero otherwise. Long-term winning and losing industry are defined as the top and bottom three industries ranked on five-year value-weighted average industry returns. The coefficient diffidence between $b_{11 j t}-b_{10 j t}$ in Panel A can be interpreted as industry contrarian returns with neutral stock performance. The coefficient diffidence between $b_{11 j t}-b_{10 j t}$ in Panel B can be interpreted as stock contrarian returns with neutral industry performance. The coefficient estimates of a given independent variable are average over $j=1,2, \ldots, 12$ for column labelled $(1,12), j=13,14, \ldots, 24$ for column $(13,24) \ldots$ and $j=1,2, \ldots, 60$ for columns labelled $(1,60)$. The numbers reported in the table are the time series averages of these averages in percentage per month. NeweyWest (1987) adjusted $t$-statistics are reported in parentheses. Coefficients on control variables are omitted for brevity. 


\begin{tabular}{|c|c|c|c|c|c|c|c|c|c|c|c|c|}
\hline & $\begin{array}{l}\text { Monthly } \\
\text { return } \\
(1,12)\end{array}$ & $\begin{array}{l}\text { (2) } \\
\text { Monthly } \\
\text { return } \\
(1,12) \text { Jan } \\
\& \text { Apr } \\
\text { Excl. }\end{array}$ & $\begin{array}{l}\text { Monthly } \\
\text { return } \\
(13,24)\end{array}$ & $\begin{array}{l}(4) \\
\text { Monthly } \\
\text { return } \\
(13,24) \text { Jan } \\
\& \text { Apr } \\
\text { Excl. }\end{array}$ & $\begin{array}{l}\text { Monthly } \\
\text { return } \\
(25,36)\end{array}$ & $\begin{array}{l}(6) \\
\text { Monthly } \\
\text { return } \\
(25,36) \text { Jan } \\
\text { \& Apr } \\
\text { Excl. } \\
\quad \text { Pane }\end{array}$ & $\begin{array}{l}\text { Monthly } \\
\text { return } \\
(37,48) \\
\text { A }\end{array}$ & $\begin{array}{l}(8) \\
\text { Monthly } \\
\text { return } \\
(37,48) \text { Jan } \\
\text { \& Apr } \\
\text { Excl. }\end{array}$ & $\begin{array}{l}\text { Monthly } \\
\text { return } \\
(49,60)\end{array}$ & $\begin{array}{l}(10) \\
\text { Monthly } \\
\text { return } \\
(49,60) \text { Jan } \\
\text { \& Apr } \\
\text { Excl. }\end{array}$ & $\begin{array}{l}\text { Monthly } \\
\text { return } \\
(1,60)\end{array}$ & $\begin{array}{l}(12) \\
\text { Monthly } \\
\text { return } \\
(1,60) \text { Jan } \\
\text { \& Apr } \\
\text { Excl. }\end{array}$ \\
\hline 5-year winner & $\begin{array}{l}0.03 \\
(0.56)\end{array}$ & $\begin{array}{l}0.05 \\
(0.78)\end{array}$ & $\begin{array}{l}0.03 \\
(0.58)\end{array}$ & $\begin{array}{l}0.07 \\
(1.01)\end{array}$ & $\begin{array}{l}0.04 \\
(0.72)\end{array}$ & $\begin{array}{l}0.05 \\
(0.71)\end{array}$ & $\begin{array}{l}0.03 \\
(0.56)\end{array}$ & $\begin{array}{l}0.05 \\
(0.93)\end{array}$ & $\begin{array}{l}-0.09 \\
(-1.53)\end{array}$ & $\begin{array}{l}-0.09 \\
(-1.43)\end{array}$ & $\begin{array}{l}0.00 \\
(0.08)\end{array}$ & $\begin{array}{l}0.04 \\
(0.74)\end{array}$ \\
\hline 5-year loser & $\begin{array}{l}0.14 \\
(1.61)\end{array}$ & $\begin{array}{l}0.02 \\
(0.18)\end{array}$ & $\begin{array}{l}0.13 \\
(1.65)\end{array}$ & $\begin{array}{l}0.06 \\
(0.81)\end{array}$ & $\begin{array}{l}0.11 \\
(1.44)\end{array}$ & $\begin{array}{l}0.08 \\
(0.93)\end{array}$ & $\begin{array}{l}0.17 \\
(2.35)\end{array}$ & $\begin{array}{l}0.11 \\
(1.34)\end{array}$ & $\begin{array}{l}0.05 \\
(0.08)\end{array}$ & $\begin{array}{l}-0.02 \\
(-0.26)\end{array}$ & $\begin{array}{l}0.11 \\
(1.90)\end{array}$ & $\begin{array}{l}0.06 \\
(1.03)\end{array}$ \\
\hline $\begin{array}{l}\text { Neutral }^{\text {stock } *} \\
\text { 5year Winning Ind }\end{array}$ & $\begin{array}{l}-0.00 \\
(-0.04)\end{array}$ & $\begin{array}{l}0.09 \\
(0.83)\end{array}$ & $\begin{array}{l}-0.01 \\
(-0.07)\end{array}$ & $\begin{array}{l}0.01 \\
(0.14)\end{array}$ & $\begin{array}{l}0.04 \\
(0.41)\end{array}$ & $\begin{array}{l}0.03 \\
(0.22)\end{array}$ & $\begin{array}{l}0.06 \\
(0.51)\end{array}$ & $\begin{array}{l}0.07 \\
(0.52)\end{array}$ & $\begin{array}{l}-0.22 \\
(-1.77)\end{array}$ & $\begin{array}{l}-0.21 \\
(-1.48)\end{array}$ & $\begin{array}{l}-0.03 \\
(-0.17)\end{array}$ & $\begin{array}{l}0.00 \\
(0.40)\end{array}$ \\
\hline $\begin{array}{l}\text { Neutral }^{\text {stock* }} \text {. } \\
\text { 5year Losing Ind }\end{array}$ & $\begin{array}{l}0.11 \\
(1.25)\end{array}$ & $\begin{array}{l}0.18 \\
(1.97)\end{array}$ & $\begin{array}{l}0.17 \\
(1.76)\end{array}$ & $\begin{array}{l}0.22 \\
(2.20)\end{array}$ & $\begin{array}{l}0.31 \\
(3.17)\end{array}$ & $\begin{array}{l}0.28 \\
(2.63)\end{array}$ & $\begin{array}{l}0.37 \\
(3.64)\end{array}$ & $\begin{array}{l}0.42 \\
(3.66)\end{array}$ & $\begin{array}{l}0.36 \\
(3.57)\end{array}$ & $\begin{array}{l}0.39 \\
(3.45)\end{array}$ & $\begin{array}{l}0.26 \\
(3.75)\end{array}$ & $\begin{array}{l}0.30 \\
(3.87)\end{array}$ \\
\hline \multirow[t]{2}{*}{$\begin{array}{l}\text { 5year losing Ind- 5year winning Ind } \\
\text { amg Neutral }^{\text {stock }}\end{array}$} & $\begin{array}{l}0.11 \\
(0.82)\end{array}$ & $\begin{array}{l}0.08 \\
(0.60)\end{array}$ & $\begin{array}{l}0.17 \\
(1.52)\end{array}$ & $\begin{array}{l}0.20 \\
(1.75)\end{array}$ & $\begin{array}{l}0.26 \\
(1.95)\end{array}$ & $\begin{array}{l}0.25 \\
(1.73)\end{array}$ & $\begin{array}{l}0.31 \\
(2.03)\end{array}$ & $\begin{array}{l}0.34 \\
(2.25)\end{array}$ & $\begin{array}{l}0.58 \\
(3.98)\end{array}$ & $\begin{array}{l}0.60 \\
(3.96)\end{array}$ & $\begin{array}{l}0.29 \\
(2.08)\end{array}$ & $\begin{array}{l}0.30 \\
(2.05)\end{array}$ \\
\hline & \multicolumn{12}{|c|}{ Panel B } \\
\hline 5year winning Ind & $\begin{array}{l}-0.11 \\
(-1.03)\end{array}$ & $\begin{array}{l}0.01 \\
(0.07)\end{array}$ & $\begin{array}{l}-0.04 \\
(-0.42)\end{array}$ & $\begin{array}{l}-0.02 \\
(-0.16)\end{array}$ & $\begin{array}{l}0.14 \\
(1.42)\end{array}$ & $\begin{array}{l}0.13 \\
(1.30)\end{array}$ & $\begin{array}{l}0.12 \\
(1.12)\end{array}$ & $\begin{array}{l}0.12 \\
(1.17)\end{array}$ & $\begin{array}{l}-0.14 \\
(-1.39)\end{array}$ & $\begin{array}{l}-0.14 \\
(-1.16)\end{array}$ & $\begin{array}{l}-0.01 \\
(-0.08)\end{array}$ & $\begin{array}{l}0.02 \\
(0.31)\end{array}$ \\
\hline 5year losing Ind & $\begin{array}{l}0.04 \\
(0.38)\end{array}$ & $\begin{array}{l}0.05 \\
(0.46)\end{array}$ & $\begin{array}{l}0.15 \\
(1.59)\end{array}$ & $\begin{array}{l}0.19 \\
(1.82)\end{array}$ & $\begin{array}{l}0.31 \\
(3.12)\end{array}$ & $\begin{array}{l}0.32 \\
(2.90)\end{array}$ & $\begin{array}{l}0.40 \\
(3.96)\end{array}$ & $\begin{array}{l}0.42 \\
(3.89)\end{array}$ & $\begin{array}{l}0.44 \\
(4.14)\end{array}$ & $\begin{array}{l}0.47 \\
(4.00)\end{array}$ & $\begin{array}{l}0.27 \\
(3.54)\end{array}$ & $\begin{array}{l}0.29 \\
(3.53)\end{array}$ \\
\hline $\begin{array}{l}\text { Neutral }^{\text {industry* }} \\
\text { 5-year winner }\end{array}$ & $\begin{array}{l}0.02 \\
(0.34)\end{array}$ & $\begin{array}{l}0.08 \\
(1.51)\end{array}$ & $\begin{array}{l}0.01 \\
(0.27)\end{array}$ & $\begin{array}{l}0.04 \\
(0.59)\end{array}$ & $\begin{array}{l}0.06 \\
(1.11)\end{array}$ & $\begin{array}{l}0.08 \\
(1.15)\end{array}$ & $\begin{array}{l}0.08 \\
(1.46)\end{array}$ & $\begin{array}{l}0.10 \\
(1.60)\end{array}$ & $\begin{array}{l}-0.03 \\
(-0.52)\end{array}$ & $\begin{array}{l}-0.03 \\
(-0.44)\end{array}$ & $\begin{array}{l}0.03 \\
(0.68)\end{array}$ & $\begin{array}{l}0.06 \\
(1.20)\end{array}$ \\
\hline $\begin{array}{l}\text { Neutral }^{\text {industry }} \\
\text { 5-year loser }\end{array}$ & $\begin{array}{l}-0.03 \\
(-0.30)\end{array}$ & $\begin{array}{l}-0.10 \\
(-1.49)\end{array}$ & $\begin{array}{l}0.03 \\
(0.34)\end{array}$ & $\begin{array}{l}-0.04 \\
(0.59)\end{array}$ & $\begin{array}{l}0.01 \\
(0.15)\end{array}$ & $\begin{array}{l}-0.06 \\
(-0.68)\end{array}$ & $\begin{array}{l}0.13 \\
(1.68)\end{array}$ & $\begin{array}{l}0.11 \\
(1.36)\end{array}$ & $\begin{array}{l}0.02 \\
(0.24)\end{array}$ & $\begin{array}{l}-0.02 \\
(-0.24)\end{array}$ & $\begin{array}{l}0.03 \\
(0.44)\end{array}$ & $\begin{array}{l}-0.03 \\
(-0.43)\end{array}$ \\
\hline $\begin{array}{l}\text { 5-year loser-5-year winner } \\
\text { amg Neutral }\end{array}$ & $\begin{array}{l}-0.05 \\
(-0.42)\end{array}$ & $\begin{array}{l}-0.18 \\
(-1.85)\end{array}$ & $\begin{array}{l}0.01 \\
(0.11)\end{array}$ & $\begin{array}{l}-0.08 \\
(-0.70)\end{array}$ & $\begin{array}{l}-0.06 \\
(-0.78)\end{array}$ & $\begin{array}{l}-0.13 \\
(-1.24)\end{array}$ & $\begin{array}{l}0.05 \\
(0.55)\end{array}$ & $\begin{array}{l}0.00 \\
(0.09)\end{array}$ & $\begin{array}{l}0.05 \\
(0.32)\end{array}$ & $\begin{array}{l}0.01 \\
(0.07)\end{array}$ & $\begin{array}{l}-0.00 \\
(-0.04)\end{array}$ & $\begin{array}{l}-0.09 \\
(-1.08)\end{array}$ \\
\hline
\end{tabular}




\section{Table 5 Adjusting for past performance}

We estimate $60(j=1, \ldots, 60)$ cross-sectional regressions on a monthly basis between February 1980 and December 2011 as following for Panel A

$$
\begin{aligned}
& R_{i t}=b_{0 j t}+b_{1 j t} R_{i, t-1}+b_{2 j t} \text { size }_{i, t-1}+b_{3 j t} \text { BM }_{i, t-1}+b_{4 j t} 52 w_{k h W i n n e r}{ }_{i, t-j}+b_{5 j t} 52 \text { wkhLoser }_{i, t-j}+b_{6 j t} \text { IndMomWinner }_{i, t-j}+b_{7 j t} \text { IndMomLoser }_{i, t-j} \\
& +b_{8 j t} \text { 5yearWinningInd }_{i, t-j}+b_{9 j t} \text { 5yearLosingInd }{ }_{i, t-j}+b_{10 j t} \text { 5yearWinner }_{i, t-j}^{\text {Excess }}+b_{11 j t} \text { 5yearLoser }{ }_{i, t-j}^{\text {Excess }}+e_{i j t}
\end{aligned}
$$

The following equation is estimated for Panel B.

$$
\begin{aligned}
R_{i t}= & b_{0 j t}+b_{1 j t} R_{i, t-1}+b_{2 j t} \text { size }_{i, t-1}+b_{3 j t} \text { BM }_{i, t-1}+b_{4 j t} 52 \text { wkhWinner }_{i, t-j}+b_{5 j t} 52 \text { whhLoser }_{i, t-j}+b_{6 j t} \text { IndMomWinner }_{i, t-j}+b_{7 j t} \text { IndMomLoser }_{i, t-j} \\
& +b_{8 j t} \text { 5yearWinner }{ }_{i, t-j}+b_{9 j t} \text { 5yearLoser }{ }_{i, t-j}+b_{10 j t} \text { 5yearWinnningInd } \text { Excess }_{i, t-j}+b_{11 j t} \text { 5yearLosingInd }_{i, t-j}^{\text {Excess }}+e_{i j t}
\end{aligned}
$$

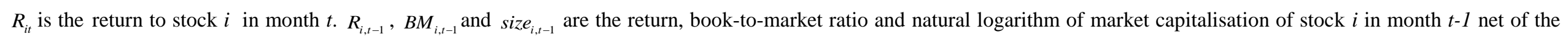

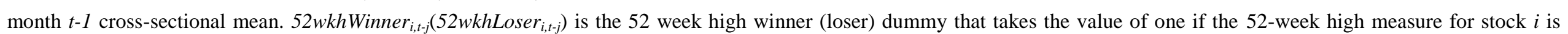

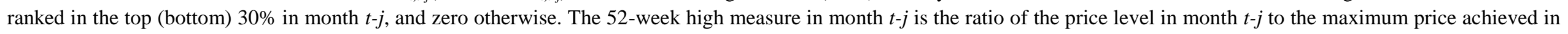

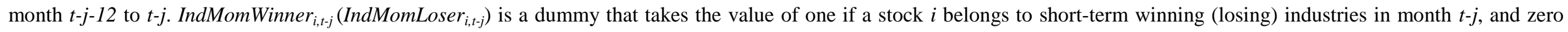

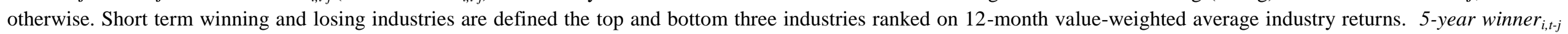

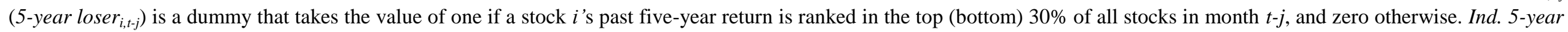

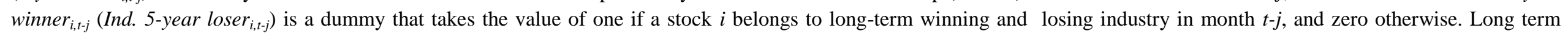

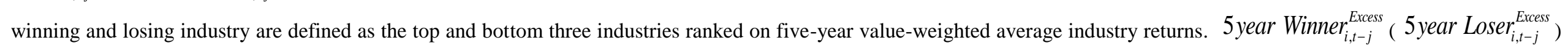

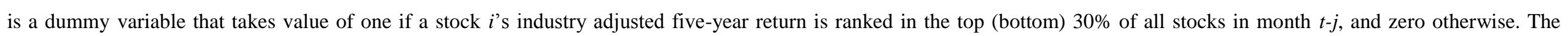

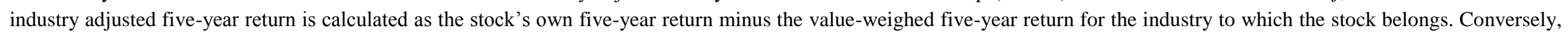

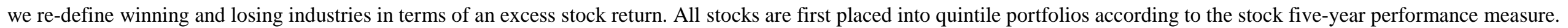

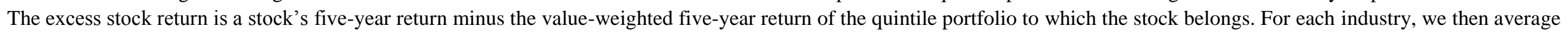

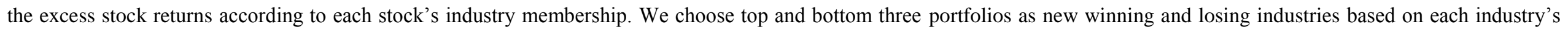

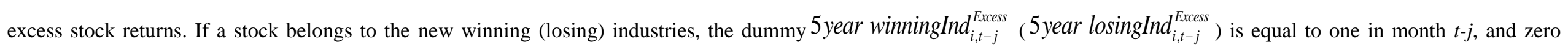

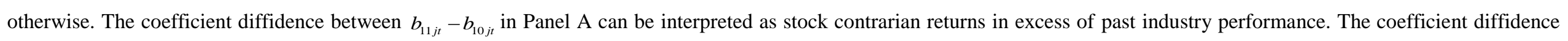

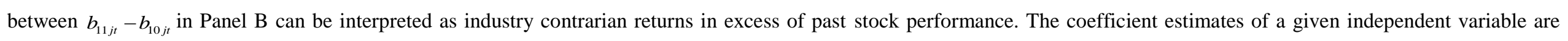

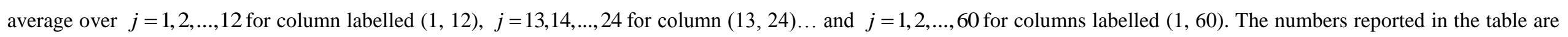

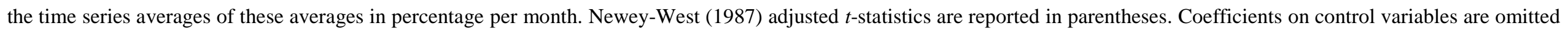
for brevity. 


\begin{tabular}{|c|c|c|c|c|c|c|c|c|c|c|c|c|}
\hline & $\begin{array}{l}\text { Monthly } \\
\text { return } \\
(1,12)\end{array}$ & $\begin{array}{l}(2) \\
\text { Monthly } \\
\text { return } \\
(1,12) \text { Jan } \\
\& \text { Apr } \\
\text { Excl. }\end{array}$ & $\begin{array}{l}\text { Monthly } \\
\text { return } \\
(13,24)\end{array}$ & $\begin{array}{l}\text { Monthly } \\
\text { return } \\
(13,24) \text { Jan } \\
\text { \& Apr } \\
\text { Excl. }\end{array}$ & $\begin{array}{l}\text { Monthly } \\
\text { return } \\
(25,36)\end{array}$ & $\begin{array}{l}(6) \\
\text { Monthly } \\
\text { return } \\
(25,36) \text { Jan } \\
\& \text { Apr } \\
\text { Excl. } \\
\quad \text { Par }\end{array}$ & $\begin{array}{l}\text { Monthly } \\
\text { return } \\
(37,48) \\
\text { el A }\end{array}$ & $\begin{array}{l}(8) \\
\text { Monthly } \\
\text { return } \\
(37,48) \text { Jan } \\
\text { \& Apr } \\
\text { Excl. }\end{array}$ & $\begin{array}{l}\text { Monthly } \\
\text { return } \\
(49,60)\end{array}$ & $\begin{array}{l}(10) \\
\text { Monthly } \\
\text { return } \\
(49,60) \text { Jan } \\
\& \text { Apr } \\
\text { Excl. }\end{array}$ & $\begin{array}{l}\text { Monthly } \\
\text { return } \\
(1,60)\end{array}$ & $\begin{array}{l}(12) \\
\text { Monthly } \\
\text { return } \\
(1,60) \text { Jan } \\
\& \text { Apr } \\
\text { Excl. }\end{array}$ \\
\hline 5-year winning Ind & $\begin{array}{l}-0.06 \\
(-0.60)\end{array}$ & $\begin{array}{l}0.07 \\
(0.64)\end{array}$ & $\begin{array}{l}-0.01 \\
(-0.09)\end{array}$ & $\begin{array}{l}0.03 \\
(0.27)\end{array}$ & $\begin{array}{l}0.09 \\
(1.21)\end{array}$ & $\begin{array}{l}0.08 \\
(1.19)\end{array}$ & $\begin{array}{l}0.09 \\
(0.83)\end{array}$ & $\begin{array}{l}0.10 \\
(0.84)\end{array}$ & $\begin{array}{l}-0.10 \\
(-1.20)\end{array}$ & $\begin{array}{l}-0.10 \\
(-0.99)\end{array}$ & $\begin{array}{l}0.01 \\
(0.17)\end{array}$ & $\begin{array}{l}0.05 \\
(0.62)\end{array}$ \\
\hline 5-year losing Ind & $\begin{array}{l}0.04 \\
(0.45)\end{array}$ & $\begin{array}{l}0.04 \\
0.37)\end{array}$ & $\begin{array}{l}0.15 \\
(1.68)\end{array}$ & $\begin{array}{l}0.20 \\
(1.92)\end{array}$ & $\begin{array}{l}0.31 \\
(3.30)\end{array}$ & $\begin{array}{l}0.32 \\
(3.13)\end{array}$ & $\begin{array}{l}0.37 \\
(4.01)\end{array}$ & $\begin{array}{l}0.40 \\
(3.89)\end{array}$ & $\begin{array}{l}0.44 \\
(4.30)\end{array}$ & $\begin{array}{l}0.48 \\
(4.18)\end{array}$ & $\begin{array}{l}0.26 \\
(3.70)\end{array}$ & $\begin{array}{l}0.29 \\
(3.66)\end{array}$ \\
\hline 5-year winner ${ }^{\text {Excess }}$ & $\begin{array}{l}0.05 \\
(1.05)\end{array}$ & $\begin{array}{l}0.09 \\
(1.60)\end{array}$ & $\begin{array}{l}0.02 \\
(0.50)\end{array}$ & $\begin{array}{l}0.04 \\
(0.63)\end{array}$ & $\begin{array}{l}0.03 \\
(0.60)\end{array}$ & $\begin{array}{l}0.05 \\
(0.74)\end{array}$ & $\begin{array}{l}0.05 \\
(1.02)\end{array}$ & $\begin{array}{l}0.06 \\
(1.44)\end{array}$ & $\begin{array}{l}-0.04 \\
(-0.82)\end{array}$ & $\begin{array}{l}-0.04 \\
(-0.68)\end{array}$ & $\begin{array}{l}0.03 \\
(0.62)\end{array}$ & $\begin{array}{l}0.05 \\
(1.05)\end{array}$ \\
\hline 5 -year loser ${ }^{\text {Excess }}$ & $\begin{array}{l}0.04 \\
(0.47)\end{array}$ & $\begin{array}{l}-0.07 \\
(-0.89)\end{array}$ & $\begin{array}{l}0.04 \\
(0.56)\end{array}$ & $\begin{array}{l}-0.02 \\
(-0.23)\end{array}$ & $\begin{array}{l}0.01 \\
(0.22)\end{array}$ & $\begin{array}{l}0.00 \\
(0.06)\end{array}$ & $\begin{array}{l}0.15 \\
(1.96)\end{array}$ & $\begin{array}{l}0.12 \\
(1.61)\end{array}$ & $\begin{array}{l}0.02 \\
(0.35)\end{array}$ & $\begin{array}{l}0.00 \\
(0.02)\end{array}$ & $\begin{array}{l}0.05 \\
(1.01)\end{array}$ & $\begin{array}{l}0.02 \\
(0.26)\end{array}$ \\
\hline $\begin{array}{l}\text { 5-year loser }{ }^{\text {Excess }} \text { - } \\
\text { 5-year winner }\end{array}$ & $\begin{array}{l}-0.02 \\
(-0.20)\end{array}$ & $\begin{array}{l}-0.15 \\
(-1.75)\end{array}$ & $\begin{array}{l}0.01 \\
(0.11)\end{array}$ & $\begin{array}{l}-0.06 \\
(-0.58)\end{array}$ & $\begin{array}{l}-0.02 \\
(-0.24)\end{array}$ & $\begin{array}{l}-0.04 \\
(-0.46)\end{array}$ & $\begin{array}{l}0.10 \\
(1.33)\end{array}$ & $\begin{array}{l}0.07 \\
(1.02)\end{array}$ & $\begin{array}{l}0.06 \\
(0.82)\end{array}$ & $\begin{array}{l}0.04 \\
(0.48)\end{array}$ & $\begin{array}{l}0.03 \\
(0.42)\end{array}$ & $\begin{array}{l}-0.03 \\
(-0.48)\end{array}$ \\
\hline 5-year winner & $\begin{array}{l}0.01 \\
(0.17)\end{array}$ & $\begin{array}{l}0.08 \\
(1.52)\end{array}$ & $\begin{array}{l}0.01 \\
(0.14)\end{array}$ & $\begin{array}{l}0.03 \\
(0.50)\end{array}$ & $\begin{array}{l}0.01 \\
(0.14)\end{array}$ & $\begin{array}{l}0.02 \\
(0.36)\end{array}$ & $\begin{array}{l}\text { el B } \\
-0.00 \\
(-0.08)\end{array}$ & $\begin{array}{l}0.02 \\
(0.38)\end{array}$ & $\begin{array}{l}-0.06 \\
(-1.16)\end{array}$ & $\begin{array}{l}-0.05 \\
(-1.05)\end{array}$ & $\begin{array}{l}-0.00 \\
(-0.16)\end{array}$ & $\begin{array}{l}0.02 \\
(0.08)\end{array}$ \\
\hline 5-year loser & $\begin{array}{l}-0.00 \\
(-0.01)\end{array}$ & $\begin{array}{l}-0.14 \\
(-1.53)\end{array}$ & $\begin{array}{l}0.08 \\
(1.04)\end{array}$ & $\begin{array}{l}0.00 \\
(0.10)\end{array}$ & $\begin{array}{l}0.09 \\
(1.33)\end{array}$ & $\begin{array}{l}0.05 \\
(0.75)\end{array}$ & $\begin{array}{l}0.15 \\
(1.96)\end{array}$ & $\begin{array}{l}0.10 \\
(1.60)\end{array}$ & $\begin{array}{l}0.12 \\
(2.06)\end{array}$ & $\begin{array}{l}0.09 \\
(1.41)\end{array}$ & $\begin{array}{l}0.08 \\
(1.68)\end{array}$ & $\begin{array}{l}0.02 \\
(0.49)\end{array}$ \\
\hline 5year winning Ind ${ }^{\text {Excess }}$ & $\begin{array}{l}-0.07 \\
(-0.67)\end{array}$ & $\begin{array}{l}-0.06 \\
(-0.41)\end{array}$ & $\begin{array}{l}-0.12 \\
(-1.09)\end{array}$ & $\begin{array}{l}-0.15 \\
(-1.14)\end{array}$ & $\begin{array}{l}-0.06 \\
(-0.42)\end{array}$ & $\begin{array}{l}-0.06 \\
(-0.44)\end{array}$ & $\begin{array}{l}-0.08 \\
(-0.57)\end{array}$ & $\begin{array}{l}-0.08 \\
(-0.54)\end{array}$ & $\begin{array}{l}-0.18 \\
(-1.53)\end{array}$ & $\begin{array}{l}-0.14 \\
(-1.14)\end{array}$ & $\begin{array}{l}-0.09 \\
(-0.88)\end{array}$ & $\begin{array}{l}-0.08 \\
(-0.75)\end{array}$ \\
\hline 5year losing Ind ${ }^{\text {Excess }}$ & $\begin{array}{l}0.12 \\
(1.33)\end{array}$ & $\begin{array}{l}0.13 \\
(1.17)\end{array}$ & $\begin{array}{l}0.14 \\
(1.49)\end{array}$ & $\begin{array}{l}0.17 \\
(1.66)\end{array}$ & $\begin{array}{l}0.17 \\
(1.83)\end{array}$ & $\begin{array}{l}0.19 \\
(1.81)\end{array}$ & $\begin{array}{l}0.10 \\
(1.11)\end{array}$ & $\begin{array}{l}0.14 \\
(1.42)\end{array}$ & $\begin{array}{l}0.19 \\
(2.01)\end{array}$ & $\begin{array}{l}0.23 \\
(2.16)\end{array}$ & $\begin{array}{l}0.16 \\
(2.29)\end{array}$ & $\begin{array}{l}0.19 \\
(2.40)\end{array}$ \\
\hline $\begin{array}{l}\text { 5year losing Ind }{ }^{\text {Excess }}- \\
\text { 5year winning Ind } \\
\text { Excess }\end{array}$ & $\begin{array}{l}0.18 \\
(1.25)\end{array}$ & $\begin{array}{l}0.18 \\
(1.03)\end{array}$ & $\begin{array}{l}0.26 \\
(1.66)\end{array}$ & $\begin{array}{l}0.33 \\
(1.77)\end{array}$ & $\begin{array}{l}0.23 \\
(1.29)\end{array}$ & $\begin{array}{l}0.25 \\
(1.28)\end{array}$ & $\begin{array}{l}0.18 \\
(1.01)\end{array}$ & $\begin{array}{l}0.23 \\
(1.14)\end{array}$ & $\begin{array}{l}0.35 \\
(2.53)\end{array}$ & $\begin{array}{l}0.36 \\
(2.07)\end{array}$ & $\begin{array}{l}0.25 \\
(1.93)\end{array}$ & $\begin{array}{l}0.27 \\
(1.84)\end{array}$ \\
\hline
\end{tabular}


Table 6 Comparisons between within industry and inter-industry reversals

We estimate $60(j=1, \ldots, 60)$ cross-sectional regressions on a monthly basis between February 1980 and December 2011

$R_{i t}=b_{0 j t}+b_{1 j t} R_{i, t-1}+b_{2 j t}$ size $_{i, t-1}+b_{3 j t}$ BM $_{i, t-1}+b_{4 j t} 52 w k h$ Winner $_{i, t-j}+b_{5 j t} 52 w k h$ Loser $_{i, t-j}+b_{6 j t}$ IndMomWinner $_{i, t-j}+b_{7 j t}$ IndMomLoser $_{i, t-j}$

$+b_{8 j t}$ Ind 5 yearWinner $_{i, t-j}^{\text {within }}+b_{9 j t}$ Ind 5 yearLoser $_{i, t-j}^{\text {within }}+b_{10 j t}$ 5yearWinningInd $_{i, t-j}+b_{11 j t}$ 5yearLosingInd ${ }_{i, t-j}+e_{i j t}$

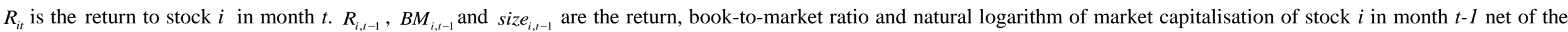

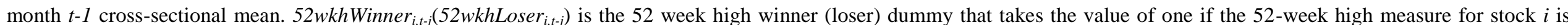

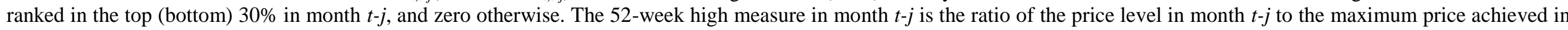

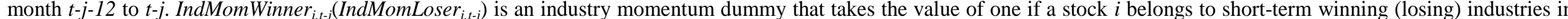

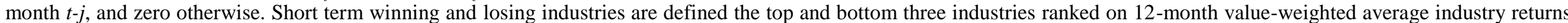

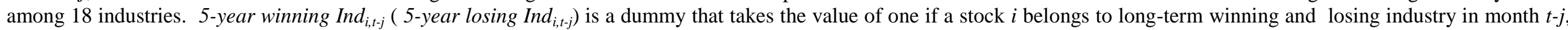

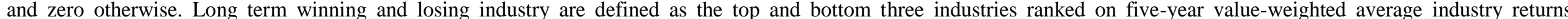

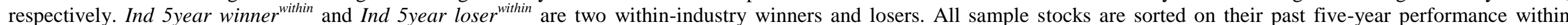

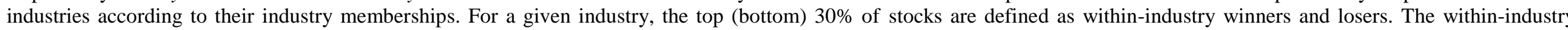

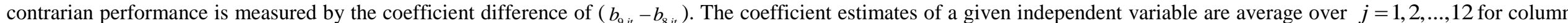

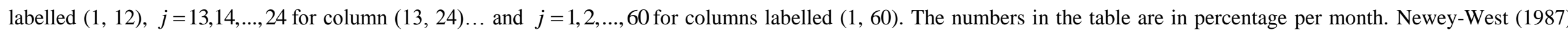
adjusted $t$-statistics are reported in parentheses. Coefficients on control variables are omitted for brevity.

\begin{tabular}{|c|c|c|c|c|c|c|c|c|c|c|c|c|}
\hline & (1) & (2) & (3) & (4) & $(5)$ & (6) & (7) & $(8)$ & (9) & (10) & (11) & (12) \\
\hline & $\begin{array}{l}\text { Monthly } \\
\text { return } \\
(1,12)\end{array}$ & $\begin{array}{l}\text { Monthly } \\
\text { return }(1,12) \\
\text { Jan \& Apr } \\
\text { Excl. }\end{array}$ & $\begin{array}{l}\text { Monthly } \\
\text { return } \\
(13,24)\end{array}$ & $\begin{array}{l}\text { Monthly } \\
\text { return } \\
(13,24) \text { Jan } \\
\text { \& Apr Excl. }\end{array}$ & $\begin{array}{l}\text { Monthly } \\
\text { return } \\
(25,36)\end{array}$ & $\begin{array}{l}\text { Monthly } \\
\text { return } \\
(25,36) \text { Jan } \\
\text { \& Apr Excl. }\end{array}$ & $\begin{array}{l}\text { Monthly } \\
\text { return } \\
(37,48)\end{array}$ & $\begin{array}{l}\text { Monthly } \\
\text { return }(37,48) \\
\text { Jan \& Apr } \\
\text { Excl. }\end{array}$ & $\begin{array}{l}\text { Monthly } \\
\text { return } \\
(49,60)\end{array}$ & $\begin{array}{l}\text { Monthly } \\
\text { return } \\
(49,60) \text { Jan } \\
\text { \& Apr Excl. }\end{array}$ & $\begin{array}{l}\text { Monthly } \\
\text { return } \\
(1,60)\end{array}$ & $\begin{array}{l}\text { Monthly } \\
\text { return }(1,60) \\
\text { Jan \& Apr } \\
\text { Excl. }\end{array}$ \\
\hline Ind 5year winner ${ }^{\text {within }}$ & $\begin{array}{l}0.05 \\
(1.07)\end{array}$ & $\begin{array}{l}0.10 \\
(1.89)\end{array}$ & $\begin{array}{l}0.04 \\
(0.81)\end{array}$ & $\begin{array}{l}0.06 \\
(0.81)\end{array}$ & $\begin{array}{l}0.05 \\
(0.98)\end{array}$ & $\begin{array}{l}0.06 \\
(1.07)\end{array}$ & $\begin{array}{l}0.08 \\
(1.54)\end{array}$ & $\begin{array}{l}0.09 \\
(1.63)\end{array}$ & $\begin{array}{l}-0.00 \\
(-0.16)\end{array}$ & $\begin{array}{l}-0.00 \\
(-0.08)\end{array}$ & $\begin{array}{l}0.04 \\
(1.08)\end{array}$ & $\begin{array}{l}0.06 \\
(1.41)\end{array}$ \\
\hline Ind 5year loser ${ }^{\text {within }}$ & $\begin{array}{l}-0.00 \\
(-0.10)\end{array}$ & $\begin{array}{l}-0.10 \\
(-1.68)\end{array}$ & $\begin{array}{l}-0.00 \\
(-0.09)\end{array}$ & $\begin{array}{l}-0.06 \\
(-0.80)\end{array}$ & $\begin{array}{l}-0.00 \\
(-0.13)\end{array}$ & $\begin{array}{l}-0.01 \\
(-0.09)\end{array}$ & $\begin{array}{l}0.11 \\
(1.88)\end{array}$ & $\begin{array}{l}0.12 \\
(1.77)\end{array}$ & $\begin{array}{l}0.01 \\
(0.15)\end{array}$ & $\begin{array}{l}-0.03 \\
(-0.43)\end{array}$ & $\begin{array}{l}0.02 \\
(0.43)\end{array}$ & $\begin{array}{l}-0.02 \\
(-0.41)\end{array}$ \\
\hline 5year winning Ind & $\begin{array}{l}-0.06 \\
(-0.60)\end{array}$ & $\begin{array}{l}0.05 \\
(0.71)\end{array}$ & $\begin{array}{l}-0.01 \\
(-0.13)\end{array}$ & $\begin{array}{l}0.01 \\
(0.16)\end{array}$ & $\begin{array}{l}0.10 \\
(1.59)\end{array}$ & $\begin{array}{l}0.10 \\
(1.47)\end{array}$ & $\begin{array}{l}0.11 \\
(1.02)\end{array}$ & $\begin{array}{l}0.12 \\
(1.07)\end{array}$ & $\begin{array}{l}-0.11 \\
(-1.08)\end{array}$ & $\begin{array}{l}-0.10 \\
(-0.84)\end{array}$ & $\begin{array}{l}0.02 \\
(0.20)\end{array}$ & $\begin{array}{l}0.05 \\
(0.58)\end{array}$ \\
\hline 5year losing Ind & $\begin{array}{l}0.06 \\
(0.65)\end{array}$ & $\begin{array}{l}0.06 \\
(0.71)\end{array}$ & $\begin{array}{l}0.16 \\
(1.91)\end{array}$ & $\begin{array}{l}0.21 \\
(2.08)\end{array}$ & $\begin{array}{l}0.31 \\
(3.34)\end{array}$ & $\begin{array}{l}0.32 \\
(3.15)\end{array}$ & $\begin{array}{l}0.36 \\
(3.90)\end{array}$ & $\begin{array}{l}0.39 \\
(3.77)\end{array}$ & $\begin{array}{l}0.44 \\
(4.31)\end{array}$ & $\begin{array}{l}0.48 \\
(4.20)\end{array}$ & $\begin{array}{l}0.27 \\
(3.77)\end{array}$ & $\begin{array}{l}0.29 \\
(3.78)\end{array}$ \\
\hline Ind 5year winner ${ }^{\text {within }}$ & -0.06 & -0.20 & -0.05 & -0.11 & -0.06 & -0.07 & 0.04 & 0.02 & 0.02 & -0.02 & -0.02 & -0.08 \\
\hline Ind 5year loser ${ }^{\text {within }}$ & $(-0.68)$ & $(-2.47)$ & $(-0.58)$ & $(-1.24)$ & $(-0.71)$ & $(-0.83)$ & $(0.50)$ & $(0.30)$ & $(0.23)$ & $(-0.31)$ & $(-0.38)$ & $(-1.30)$ \\
\hline $\begin{array}{l}\text { 5year losing Ind- } \\
\text { 5year winning Ind }\end{array}$ & $\begin{array}{l}0.11 \\
(0.88)\end{array}$ & $\begin{array}{l}0.01 \\
(0.09)\end{array}$ & $\begin{array}{l}0.18 \\
(1.67)\end{array}$ & $\begin{array}{l}0.19 \\
(1.70)\end{array}$ & $\begin{array}{l}0.21 \\
(1.86)\end{array}$ & $\begin{array}{l}0.21 \\
(1.87)\end{array}$ & $\begin{array}{l}0.25 \\
(1.94)\end{array}$ & $\begin{array}{l}0.27 \\
(1.91)\end{array}$ & $\begin{array}{l}0.55 \\
(3.66)\end{array}$ & $\begin{array}{l}0.57 \\
(3.43)\end{array}$ & $\begin{array}{l}0.25 \\
(2.20)\end{array}$ & $\begin{array}{l}0.24 \\
(1.98)\end{array}$ \\
\hline
\end{tabular}


Table 7 Risk-adjusted returns

We estimate $60(j=1, \ldots, 60)$ cross-sectional regressions on a monthly basis between January 1975 and December 2011

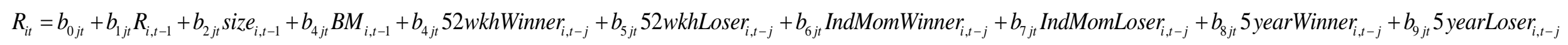

$+b_{10 j t}$ 5yearWinningInd $_{i, t-j}+b_{11 j t}$ 5yearLosingInd $_{i, t-j}+e_{i j t}$

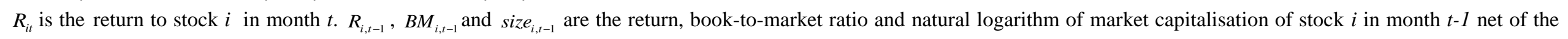

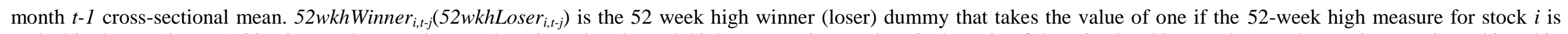

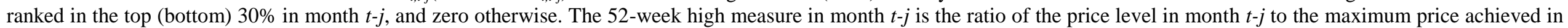

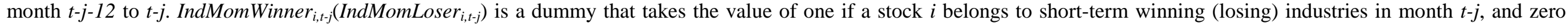

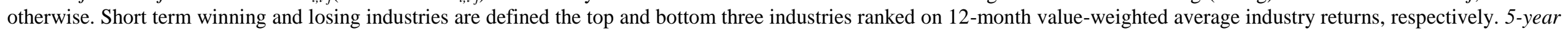

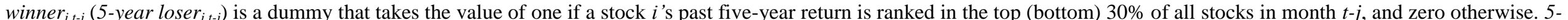

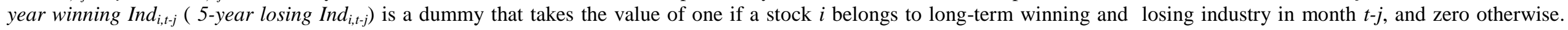

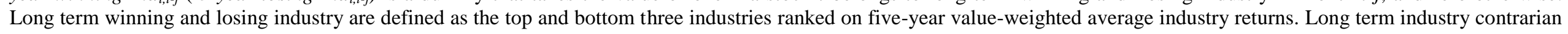

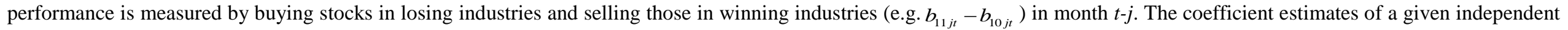

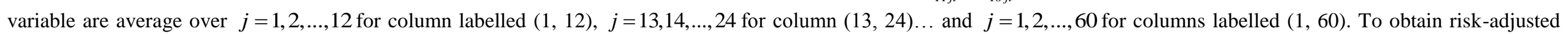

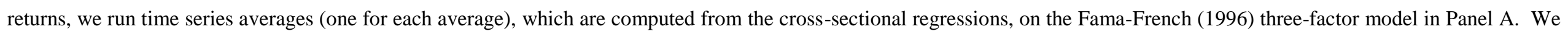

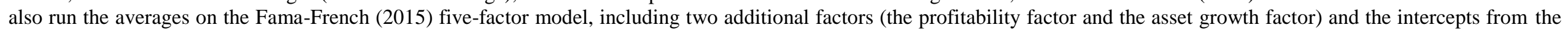
time-series regression is reported in Panel B. The numbers in the table are in percentage per month. $t$-statistics are reported in parentheses.

\begin{tabular}{|c|c|c|c|c|c|c|c|c|c|c|c|c|}
\hline & $\begin{array}{l}\text { Monthly } \\
\text { return }(1,12)\end{array}$ & $\begin{array}{l}(2) \\
\text { Monthly } \\
\text { return }(1,12) \\
\text { Jan \& Apr } \\
\text { Excl. }\end{array}$ & $\begin{array}{l}(3) \\
\text { Monthly } \\
\text { return } \\
(13,24)\end{array}$ & $\begin{array}{l}\text { (4) } \\
\text { Monthly } \\
\text { return } \\
(13,24) \text { Jan } \\
\text { \& Apr Excl. }\end{array}$ & $\begin{array}{l}(5) \\
\text { Monthly } \\
\text { return } \\
(25,36) \\
\quad \text { Panel A }\end{array}$ & $\begin{array}{l}(6) \\
\text { Monthly } \\
\text { return } \\
(25,36) \text { Jan } \\
\text { \& Apr Excl. } \\
\text { Fama-French } 3\end{array}$ & $\begin{array}{l}(7) \\
\text { Monthly } \\
\text { return } \\
(37,48) \\
\text {-Factor A }\end{array}$ & $\begin{array}{l}\text { (8) } \\
\text { Monthly } \\
\text { return } \\
(37,48) \text { Jan } \\
\text { \& Apr Excl. } \\
\text { dsted Returns }\end{array}$ & $\begin{array}{l}(9) \\
\text { Monthly } \\
\text { return } \\
(49,60)\end{array}$ & $\begin{array}{l}(10) \\
\text { Monthly } \\
\text { return } \\
(49,60) \text { Jan } \\
\text { \& Apr Excl. }\end{array}$ & $\begin{array}{l}\text { Monthly } \\
\text { return }(1,60)\end{array}$ & $\begin{array}{l}(12) \\
\text { Monthly } \\
\text { return }(1,60) \\
\text { Jan \& Apr } \\
\text { Excl. }\end{array}$ \\
\hline 5-year winner & $\begin{array}{l}-0.03 \\
(-0.60)\end{array}$ & $\begin{array}{l}0.02 \\
(0.18)\end{array}$ & $\begin{array}{l}-0.04 \\
(-0.67)\end{array}$ & $\begin{array}{l}-0.01 \\
(-0.21)\end{array}$ & $\begin{array}{l}-0.03 \\
(-0.49)\end{array}$ & $\begin{array}{l}-0.02 \\
(-0.29)\end{array}$ & $\begin{array}{l}-0.01 \\
(-0.23)\end{array}$ & $\begin{array}{l}0.00 \\
(0.03)\end{array}$ & $\begin{array}{l}-0.05 \\
(-1.18)\end{array}$ & $\begin{array}{l}-0.05 \\
(-1.09)\end{array}$ & $\begin{array}{l}-0.03 \\
(-0.80)\end{array}$ & $\begin{array}{l}-0.01 \\
(-0.30)\end{array}$ \\
\hline 5-year loser & $\begin{array}{l}-0.04 \\
(-0.49)\end{array}$ & $\begin{array}{l}-0.13 \\
(-1.68)\end{array}$ & $\begin{array}{l}0.05 \\
(0.60)\end{array}$ & $\begin{array}{l}-0.03 \\
(-0.33)\end{array}$ & $\begin{array}{l}0.06 \\
(0.95)\end{array}$ & $\begin{array}{l}0.02 \\
(0.29)\end{array}$ & $\begin{array}{l}0.12 \\
(1.68)\end{array}$ & $\begin{array}{l}0.09 \\
(0.53)\end{array}$ & $\begin{array}{l}0.02 \\
(0.46)\end{array}$ & $\begin{array}{l}-0.03 \\
(-0.86)\end{array}$ & $\begin{array}{l}0.05 \\
(0.86)\end{array}$ & $\begin{array}{l}0.02 \\
(0.41)\end{array}$ \\
\hline 5year winning Ind & $\begin{array}{l}-0.05 \\
(-0.46)\end{array}$ & $\begin{array}{l}0.03 \\
(0.21)\end{array}$ & $\begin{array}{l}-0.04 \\
(-0.34)\end{array}$ & $\begin{array}{l}-0.03 \\
(-0.30)\end{array}$ & $\begin{array}{l}0.05 \\
(0.54)\end{array}$ & $\begin{array}{l}0.04 \\
(0.42)\end{array}$ & $\begin{array}{l}0.10 \\
(1.15)\end{array}$ & $\begin{array}{l}0.08 \\
(1.21)\end{array}$ & $\begin{array}{l}-0.12 \\
(-1.15)\end{array}$ & $\begin{array}{l}-0.10 \\
(-0.92)\end{array}$ & $\begin{array}{l}-0.00 \\
(-0.07)\end{array}$ & $\begin{array}{l}0.01 \\
(0.13)\end{array}$ \\
\hline 5year losing Ind & $\begin{array}{l}0.04 \\
(0.47) \\
\end{array}$ & $\begin{array}{l}0.05 \\
(0.52) \\
\end{array}$ & $\begin{array}{l}0.17 \\
(1.93) \\
\end{array}$ & $\begin{array}{l}0.19 \\
(1.95) \\
\end{array}$ & $\begin{array}{l}0.30 \\
(3.42) \\
\end{array}$ & $\begin{array}{l}0.29 \\
(3.12) \\
\end{array}$ & $\begin{array}{l}0.36 \\
(3.54) \\
\end{array}$ & $\begin{array}{l}0.34 \\
(3.43) \\
\end{array}$ & $\begin{array}{l}0.43 \\
(3.66) \\
\end{array}$ & $\begin{array}{l}0.43 \\
(3.02) \\
\end{array}$ & $\begin{array}{l}0.26 \\
(3.09) \\
\end{array}$ & $\begin{array}{l}0.26 \\
(3.02) \\
\end{array}$ \\
\hline
\end{tabular}




\begin{tabular}{|c|c|c|c|c|c|c|c|c|c|c|c|c|}
\hline & $\begin{array}{l}1) \\
\text { Monthly } \\
\text { return } \\
(1,12)\end{array}$ & $\begin{array}{l}(2) \\
\text { Monthly } \\
\text { return }(1,12) \\
\text { Jan \& Apr } \\
\text { Excl. }\end{array}$ & $\begin{array}{l}\text { Monthly } \\
\text { return } \\
(13,24)\end{array}$ & $\begin{array}{l}\text { M) } \\
\text { Monthly } \\
\text { return }(13,24) \\
\text { Jan \& Apr } \\
\text { Excl. }\end{array}$ & $\begin{array}{l}\text { Monthly } \\
\text { return } \\
(25,36)\end{array}$ & $\begin{array}{l}(6) \\
\text { Monthly } \\
\text { return }(25,36) \\
\text { Jan \& Apr } \\
\text { Excl. }\end{array}$ & $\begin{array}{l}\text { Monthly } \\
\text { return } \\
(37,48)\end{array}$ & $\begin{array}{l}\text { Monthly return } \\
(37,48) \text { Jan \& } \\
\text { Apr Excl. }\end{array}$ & $\begin{array}{l}\text { Monthly } \\
\text { return } \\
(49,60)\end{array}$ & $\begin{array}{l}(10) \\
\text { Monthly } \\
\text { return } \\
(49,60) \text { Jan \& } \\
\text { Apr Excl. }\end{array}$ & $\begin{array}{l}\text { Monthly } \\
\text { return } \\
(1,60)\end{array}$ & $\begin{array}{l}(12) \\
\text { Monthly } \\
\text { return }(1,60) \\
\text { Jan \& Apr } \\
\text { Excl. }\end{array}$ \\
\hline 5-year loser- & -0.00 & -0.15 & 0.09 & -0.01 & 0.09 & 0.04 & 0.13 & 0.09 & 0.07 & 0.03 & 0.09 & 0.02 \\
\hline 5-year winner & $(-0.05)$ & $(-1.54)$ & $(0.85)$ & $(-0.13)$ & $(1.06)$ & $(0.42)$ & (1.55) & $(1.41)$ & $(1.05)$ & $(0.89)$ & $(1.42)$ & $(0.24)$ \\
\hline 5year losing Ind- & 0.09 & 0.02 & 0.20 & 0.23 & 0.25 & 0.24 & 0.25 & 0.26 & 0.54 & 0.53 & 0.27 & 0.25 \\
\hline \multirow[t]{2}{*}{ 5year winning Ind } & $(0.67)$ & $(0.18)$ & (1.69) & $(1.75)$ & $(1.92)$ & $(1.86)$ & $(2.32)$ & $(2.34)$ & $(3.18)$ & $(3.01)$ & $(2.54)$ & $(2.36)$ \\
\hline & \multicolumn{12}{|c|}{ Panel B Fama-French 5-Factor Adjusted Returns } \\
\hline \multirow[t]{2}{*}{ 5-year winner } & -0.05 & -0.02 & -0.06 & -0.05 & -0.06 & -0.07 & -0.05 & -0.05 & -0.07 & -0.07 & -0.05 & -0.06 \\
\hline & $(-0.98)$ & $(-0.43)$ & $(-1.02)$ & $(-0.80)$ & $(-1.12)$ & $(-1.09)$ & $(-1.03)$ & $(-0.90)$ & $(-1.26)$ & $(-1.39)$ & $(-1.41)$ & $(-1.22)$ \\
\hline \multirow[t]{2}{*}{ 5-year loser } & -0.09 & -0.19 & -0.03 & -0.10 & 0.00 & -0.06 & 0.14 & 0.09 & 0.11 & 0.06 & 0.03 & -0.05 \\
\hline & $(-1.16)$ & $(-2.24)$ & $(-0.40)$ & $(-1.27)$ & $(0.08)$ & $(-0.80)$ & (1.93) & $(1.15)$ & $(1.62)$ & $(0.77)$ & $(0.48)$ & $(-1.22)$ \\
\hline \multirow[t]{2}{*}{ 5year winning Ind } & 0.06 & 0.14 & 0.08 & 0.09 & 0.11 & 0.10 & 0.13 & 0.10 & -0.12 & -0.08 & 0.05 & 0.07 \\
\hline & $(0.59)$ & $(1.36)$ & $(0.81)$ & $(0.88)$ & $(1.01)$ & $(0.83)$ & (1.19) & $(1.45)$ & $(-1.20)$ & $(-0.78)$ & $(0.65)$ & $(0.97)$ \\
\hline \multirow[t]{2}{*}{ 5year losing Ind } & 0.02 & -0.00 & 0.13 & 0.14 & 0.31 & 0.30 & 0.38 & 0.32 & 0.31 & 0.29 & 0.24 & 0.22 \\
\hline & $(0.04)$ & $(-0.06)$ & (1.53) & $(1.49)$ & $(3.31)$ & $(2.55)$ & $(2.75)$ & $(2.60)$ & $(2.78)$ & $(2.52)$ & $(2.89)$ & $(2.86)$ \\
\hline 5-year loser- & -0.04 & -0.17 & 0.03 & -0.05 & 0.07 & 0.00 & 0.19 & 0.14 & 0.17 & 0.13 & 0.08 & 0.01 \\
\hline 5-year winner & $(-0.42)$ & $(-1.64)$ & $(0.31)$ & $(-0.50)$ & $(0.78)$ & $(0.08)$ & $(2.37)$ & $(1.60)$ & $(2.18)$ & $(1.57)$ & $(1.28)$ & $(0.18)$ \\
\hline 5year losing Ind- & -0.04 & -0.14 & 0.05 & 0.05 & 0.21 & 0.20 & 0.25 & 0.22 & 0.43 & 0.37 & 0.19 & 0.16 \\
\hline 5year winning Ind & $(-0.36)$ & $(-1.02)$ & $(0.40)$ & $(0.34)$ & $(1.78)$ & $(1.65)$ & $(1.83)$ & $(1.78)$ & (2.89) & $(2.78)$ & $(1.86)$ & $(1.52)$ \\
\hline
\end{tabular}


Table 8 The Sharpe ratio

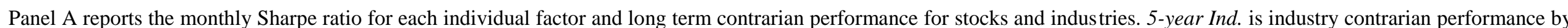

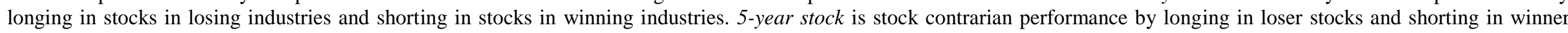

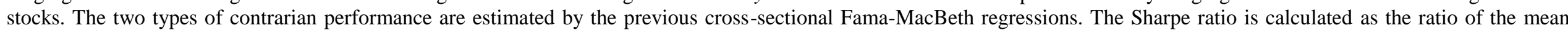

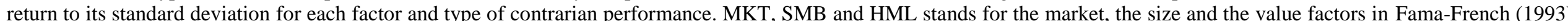

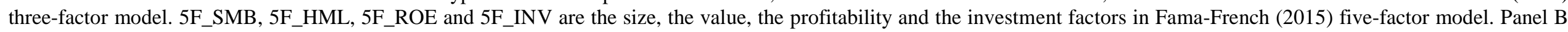

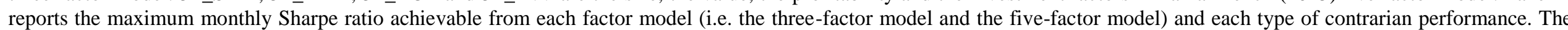

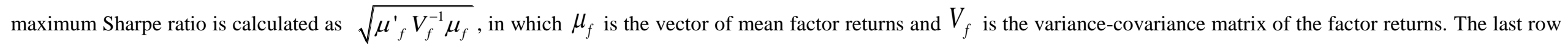

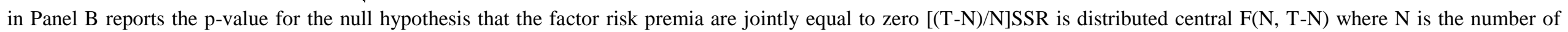
portfolios, $\mathrm{T}$ is the number of time-series observations and SSR is the maximum squared Sharpe ratio.

\begin{tabular}{|c|c|c|c|c|c|c|c|c|}
\hline \multicolumn{9}{|c|}{ Panel A Sharpe ratios } \\
\hline \multicolumn{7}{|c|}{ Individual factors } & \multicolumn{2}{|c|}{ Contrarian performance } \\
\hline MKT & SMB & HML & 5F_SMB & 5F_HML & 5F_ROE & 5F_INV & 5-year Ind. & 5-year stock \\
\hline 0.1098 & 0.0285 & 0.1032 & 0.0242 & 0.1005 & 0.0802 & 0.2512 & 0.1337 & 0.1017 \\
\hline \multicolumn{9}{|c|}{ Panel B Maximum Sharpe ratios } \\
\hline \multicolumn{3}{|c|}{ Factor models } & \multicolumn{2}{|c|}{ Contrarian performance } & & & & \\
\hline CAPM & 3F-model & $5 \mathrm{~F}$-model & 5-year Ind. & 5-year stock & & & & \\
\hline 0.1098 & 0.1503 & 0.2981 & 0.2525 & 0.1351 & & & & \\
\hline$(0.01)$ & $(0.05)$ & $(0.00)$ & $(0.00)$ & $(0.00)$ & & & & \\
\hline
\end{tabular}


Table 9 Economic States and industry contrarian performance

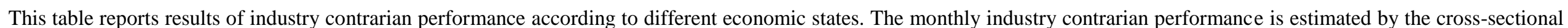

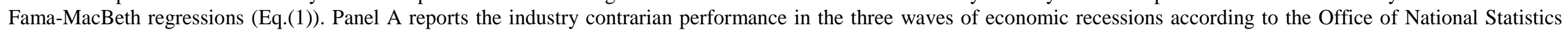

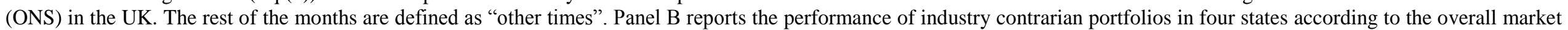

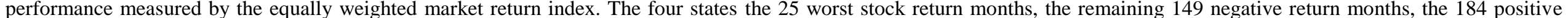

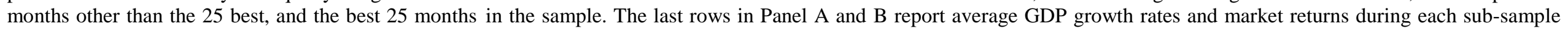
period. The numbers in the table are in percentage. Newey-West (1987) adjusted $t$-statistics are reported in parentheses.

\begin{tabular}{|c|c|c|c|c|}
\hline & \multicolumn{4}{|c|}{ Panel A: ONS Recessions } \\
\hline & 1980:Q1-1981:Q2 & 1991:Q1-1991:Q4 & 2008:Q2-2009:Q3 & Other times \\
\hline \multirow[t]{2}{*}{ Losing industries } & 0.01 & 0.37 & -0.15 & 0.32 \\
\hline & $(0.04)$ & $(1.46)$ & $(-0.89)$ & $(3.04)$ \\
\hline \multirow[t]{2}{*}{ Winning industries } & 0.23 & 0.15 & -1.55 & 0.05 \\
\hline & $(0.33)$ & $(0.49)$ & $(-2.37)$ & $(0.90)$ \\
\hline Losing industries- & -0.21 & 0.23 & 1.40 & 0.26 \\
\hline Winning industries & $(-0.36)$ & $(0.74)$ & $(2.42)$ & $(2.30)$ \\
\hline \multirow[t]{3}{*}{ Avg. GDP Growth } & -2.41 & -1.49 & -4.41 & 3.15 \\
\hline & \multicolumn{4}{|c|}{ Panel B: Classified by the overall market performance } \\
\hline & Best 25 months & Worst 25 months & Next Best and Positive(184) & Next Worst and Negative (149) \\
\hline \multirow[t]{2}{*}{ Losing industries } & 1.17 & -0.22 & 0.43 & 0.07 \\
\hline & $(2.61)$ & $(-1.18)$ & $(4.87)$ & $(0.91)$ \\
\hline \multirow[t]{2}{*}{ Winning industries } & 0.30 & -1.28 & 0.10 & 0.03 \\
\hline & $(0.69)$ & $(-3.37)$ & $(1.56)$ & $(0.42)$ \\
\hline Losing industries- & 0.87 & 1.06 & 0.33 & 0.03 \\
\hline Winning industries & $(1.84)$ & $(1.98)$ & $(2.05)$ & $(0.21)$ \\
\hline Avg. Market ret & 8.38 & -12.65 & 2.37 & -2.54 \\
\hline
\end{tabular}


Table 10 Valuation Uncertainty and Industry Contrarian Performance

This table reports industry contrarian performance conditioning on accruals, idiosyncratic volatility, competition and analyst coverage. All four conditioning variables are constructed on the industry level. We define accruals the same as Sloan (1996). Industry IVOL is the standard deviation of the residuals from regressing daily industry portfolio returns on daily FTSE All index return (the market return) from July of the last year to June of the current year. We measure industry concentration using the Herfindahl index. According to each stock's industry membership, the number of analysts is aggregated in a given industry and then is divided by the total number of firms in the industry. The sample 20 industries are separated into the top (bottom) 10 industries according to one of the four measures. We then re-run the Fama-MacBeth regressions for the two groups to obtain raw returns. By using the Fama-French three-factor (FF3) and five-factor (FF5) models, we obtain risk-adjusted returns for each portfolio. $t$-statistics are reported in parentheses

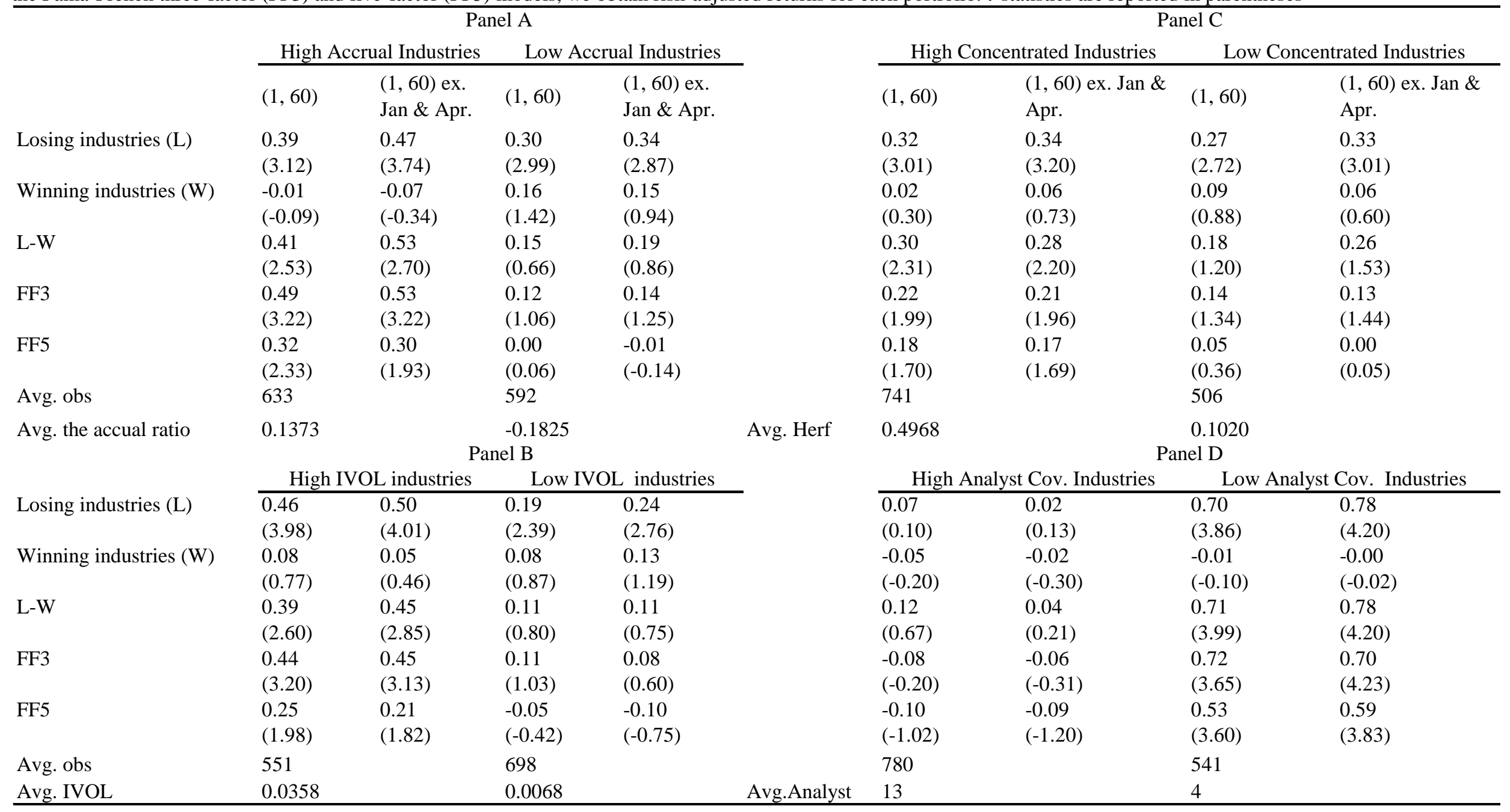




\section{Appendix}

\section{A1. Data type filters}

\begin{tabular}{ll}
\hline Non common equity & Company name or data type search \\
\hline Duplicate $^{\mathrm{a}}$ & DUPLICATE DUPL DUP DUPE DULP DUPLI \\
American Depository receipt $^{\mathrm{b}}$ & ADR GDR \\
Preferred stocks & PREFERRED PF PFD PREF 'PF' \\
Warrants & WARRANT WARRANTS WARRT \\
Debt & DEB DB DCB DEBT DEBENTURES \\
Unit Trust & TRUST UNIT TST UNIT UNIT TRUST UT \\
Investment company & INVESTMENT TRUST INVESTMENT \\
\hline
\end{tabular}

${ }^{\mathrm{a}}$ If two firms have a same name without other distinguishable characteristics, we choose the firm with an earliest coverage in the Datastream to ensure no duplicated firms included.

${ }^{b}$ We also check each stock's quoted currency and remove those that are not quoted in the British Sterling. This procedure screens out American Depository Receipts traded on LSE.

Note: This table lists words used in a screen to identify Datastream securities for which the underlying asset is not common equity. The search is carried out in the data type and in company name. 